\title{
The aeolian sedimentation record of the Thar desert
}

\author{
A K Singhvi ${ }^{1}$ and Amal $\mathrm{KAR}^{2}$ \\ ${ }^{1}$ Physical Research Laboratory, Navrangpura, Ahmedabad 380 009, India. \\ ${ }^{2}$ Central Arid Zone Research Institute, Jodhpur 342003 , India.
}

A review of the aeolian sedimentary record of the Thar desert is presented. This includes a regional survey of the major dune forms, their genesis and their relationship to climate and other regional landforms. A key aspect of this work is the chronometry of the dunes using luminescence methods. Luminescence dating of sand has enabled quantification of the duration of the phases of sand aggradation and quiescence, time scales of dune migration and the dating of pedogenic carbonates. We demonstrate that the conventional wisdom of synchronicity of dune aggradation with glacial epoch is not true in the context of Thar sands and here only a short duration window of opportunity existed for dune aggradation. Luminescence ages further suggest that this window occurred during a transitional climatic regime from glacial to interglacial about 4-10 ka after the glacial epoch. Other inferences included are that:

- the aeolian activity in the Thar began over $>150 \mathrm{ka}$, resolving that Thar is not of anthropogenic origin as suggested previously;

- the present spatial extent of the aeolian activity in the Thar is in a contracted stage compared to that in the geological past, which refutes the arguments on its rapid north-eastward expansion;

- the current dune migration rates in areas of significant human-induced disturbances are much higher than during the geological past;

- the monsoon activity in the Thar varied significantly, from being minimal during the isotopic marine stages 4 and 2 to being close to the present during stage 3;

- on shorter time scales the dune activities correlated with the lacustrine records of the region with a phase difference of a few centuries and a periodicity of $\sim 1500$ years;

- the sand aggradation climate in the southern margin in Gujarat gradually shrank northwards such that in general dunes older than 10 ka are seen in the extreme southern margin and dunes younger than $2 \mathrm{ka}$ ages occur mostly in the western part of Rajasthan.

\section{Introduction}

The Thar desert in India is the easternmost extension of the vast Saharo-Arabian deserts in the horse latitudes. The desert is dominated by the southwest monsoon, which controls both the wind vector and the vegetation cover. The configuration of atmospheric dynamics and sinking air masses in the region inhibit rain in this region despite the fact that considerable precipitable moisture exits in the atmosphere. Minor changes in the atmospheric circulation patterns result in amplified changes in the rainfall, the winds and the aeolian dynamism. This is borne out by the presence of fossil dunes in presently vegetated areas with annual rainfall in excess of $500 \mathrm{~mm}$. The region is dominated by aeolian bedforms of different dimensions, including the sand dunes. The thickness of aeolian cover can range from $1 \mathrm{~m}$ to $100 \mathrm{~m}$. Geographically, the Thar desert in India is located in the state of Rajasthan, between the foothills of the Aravalli ranges in the east and the international border with Pakistan in

Keywords. Sand dune; aeolian process; sediment; deep profile; luminescence dating; chronology; Thar; Rajasthan; Gujarat. 


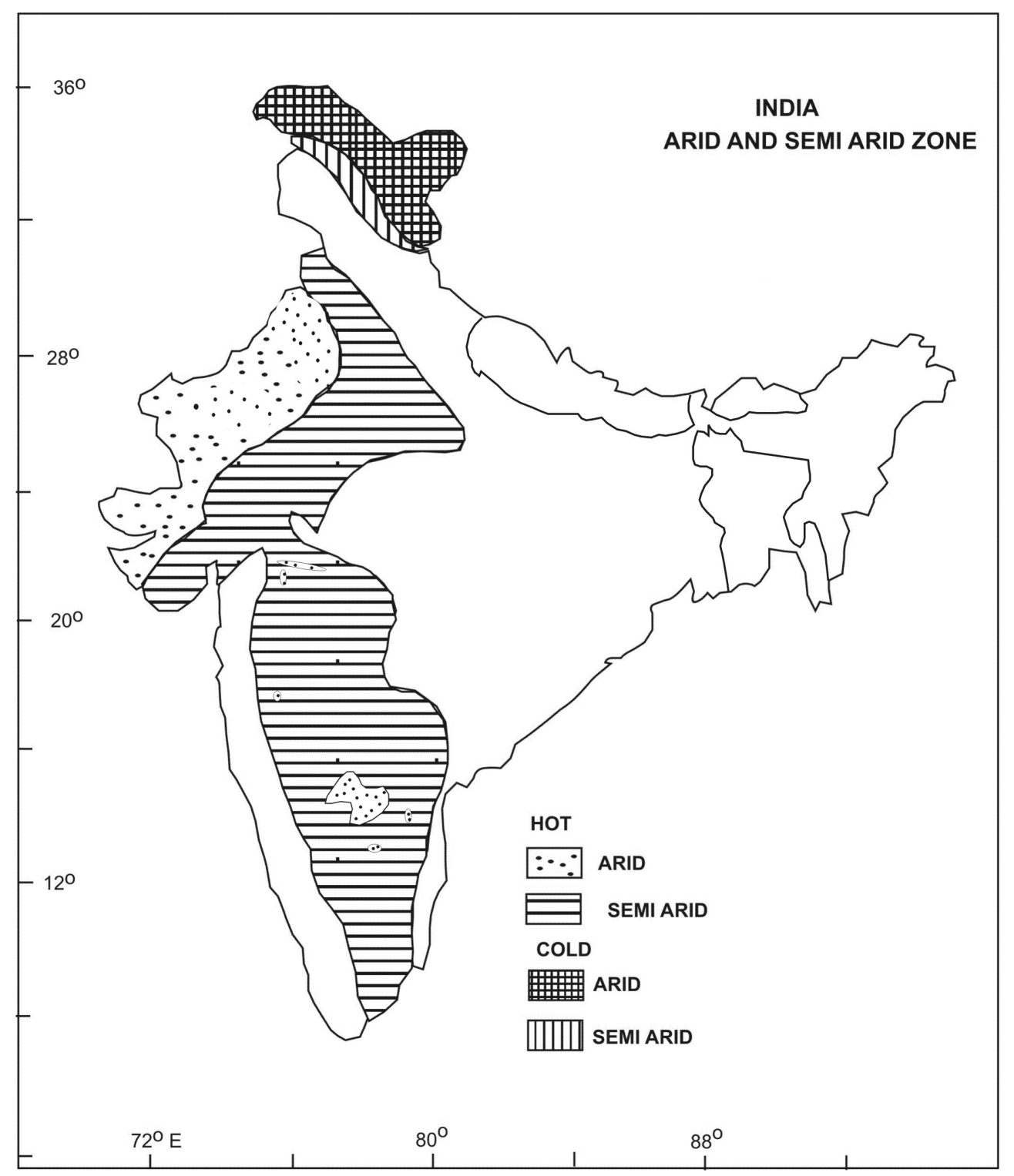

Figure 1. Arid and semi-arid zones of India (after CAZRI; reproduced from Singhvi and Kar, 1992).

the west (figure 1). Further west in Pakistan, the desert extends to the fertile alluvial plains of the Indus.

As in other deserts, the genesis of aeolian bedforms in the Thar is the result of a delicately balanced relationship between the strength and the duration of wind, sediment supply, rainfall, vegetation cover and land surface conditions. These factors not only determine the bedform development but are also crucial to its sustenance through time. Research in different deserts of the world has shown that many aeolian bedforms have developed over millennial scale and more, and that the aeolian stratigraphy faithfully records the changes in climate and other related environmental parameters (see e.g., Glennie and Singhvi 2002; Lancaster et al 2002; Bateman et al 2003). The major aeolian features that provide clues to palaeoenvironmental changes are those that accrete over a sufficiently long period of time, and have some degree of stability. The best places to find these are the desert margins, where minor perturbations can result in either stabilization and pedogenesis or reactivation. The naturally stabilised and free-forming high sand dunes, dunes formed around major obstacles, as well as the thick aeolian sand sheet deposits can be considered as the best keepers of sufficiently long records. Often the climatic changes deduced from aeolian records form a part of the global climate change and, hence, the records could be used for studying comparative evolution of sand seas in different hemispheres of the world (see for example, Pye and Tsoar 1990; Cooke et al 1993; Tchakerian 1994; Lancaster 
1995; Glennie and Singhvi 2002; Lancaster et al 2002).

Our observations of the stratigraphy of many aeolian bedforms in the Thar desert and its wetter eastern margin suggest that the deposits are not unequivocally aeolian, but contain sediments contributed by fluvial, aeolian and even lacustrine processes. The major obstacle dunes around the hills vividly record the periods of high runoff from the hills, especially as armours of subangular rock fragments strewn over the aeolian sand. The stratigraphy of the non-crescentic high sand dunes with copious vegetation suggest several episodes of dune building activities, separated by periods of landscape stability. It is not uncommon to find some fluvial and lacustrine records from within these dunes. In the following, the Quaternary environment in the Thar desert, as inferred from the sand bodies (dunes, sheets and other sand deposits) are presented. Earlier reviews on the subject are provided in Wasson et al (1983), Singhvi and Kar (1992), Dhir et al (1994), and Kar (1999).

\section{Quaternary geology}

Studies by the Geological Survey of India suggest that the Quaternary sedimentation in western Rajasthan occurred in three large basins on Precambrian and Mesozoic rocks (figure 2). Each of these basins is several hundred $\mathrm{km}$ long and up to $300 \mathrm{~m}$ deep (Wadhawan 1988; Sinha Roy et al 1998; Bakliwal and Wadhawan 2003). Bajpai et al (2000; this volume) examined the sub-surface stratigraphy in the Luni basin using bore-hole lithologs and Bouger anomaly data and reported up to $300 \mathrm{~m}$ thick sedimentation that occurred in graben depressions in the south central Thar. Overall, the Quaternary stratigraphy is simple (Singhvi and Kar 1992; figure 3). The basal members are mostly indurated fluvial sand/gravels, reflecting a semi-arid, well-watered and a high energy fluvial environment. Lower-energy fluvial sediments lie unconformably over this unit and these sediments are alternated by layers of aeolian sand and/or lacustrine mud. Induration of the basal gravels indicates periods of higher rainfall but under periods of overall semi-aridity for the calcretes to develop (Dhir et al 1994). Preliminary ESR ages on the calcretes reflect an early to middle Pleistocene age for the formation of carbonates (Kailath et al 2000; Dhir et al this volume). Detailed study of the intermediate fluvial sediments has been reported by Jain et al (1999; this volume) and a review of the geoarchaeology in the Luni basin has been provided by Mishra et al (1999).

\section{Aeolian processes and sand dunes}

\subsection{Present-day sand moving wind}

Aeolian activity in the Thar desert is mainly restricted to the period of summer winds associated with the south west monsoon. The north eastern wind of winter months plays only a minor role in aeolian activity and is largely limited to the northern fringe of the desert. Sand and dust raising winds begin from March onwards when the surface is dry and maximum wind speed $(20 \mathrm{~km} / \mathrm{h}$ or more) is reached at all the meteorological stations during June. May and July are also very windy. Since this is also the period when much of the ground flora is dry, the environment is suitable for aeolian activities. The wind and the sand dynamics cease with the arrival of monsoon rains (end of June along the eastern margin of the desert, and mid-July in the western part). Although higher wind strength and lower rainfall favour erosivity of the wind, no clear relationship between presentday wind erosion (and dune formation) and rainfall isohyet was found. Therefore, to measure the erosivity of wind and its control on sand dune formation/migration, Kar (1993a) constructed a wind erosion index, which is based on threshold wind velocity and potential evapo-transpiration for the period of strong sand-shifting wind in March to July, i.e., the period of SW monsoon before it brings the rains. The index values are classified into six groups, ranging from very low to extremely high (table 1). The maximum potential wind erosion occurs approximately southwest of Jaisalmer and decreases gradually towards east/northeast, concurrent with the increasing rainfall and decreasing wind speed. However, the wind erosion index contours cut across the isohyets, and provide a reliable measure for understanding the spatial pattern of sand mobility (figure 4). This pattern is also reflected in the spatial pattern of dune formation in the desert. According to Kar (1998), most barchans under natural conditions are formed to the west of 120 contour of the wind erosion index, while the megabarchanoids are mostly formed within the 240 contour. Kar (1993a) also showed that broadly the trends of the old dunes mimic the modern SW monsoon wind pattern, thereby implying that dune formation in the Thar is and was governed by the strength of SW monsoon wind, and that the NE wind of winter have played only a marginal role, (figure 5).

\subsection{Sand dunes and their climatic significance}

Sand dunes are the most spectacular aeolian bedforms in the Thar desert. Many different types of dunes have been identified and mapped in the 

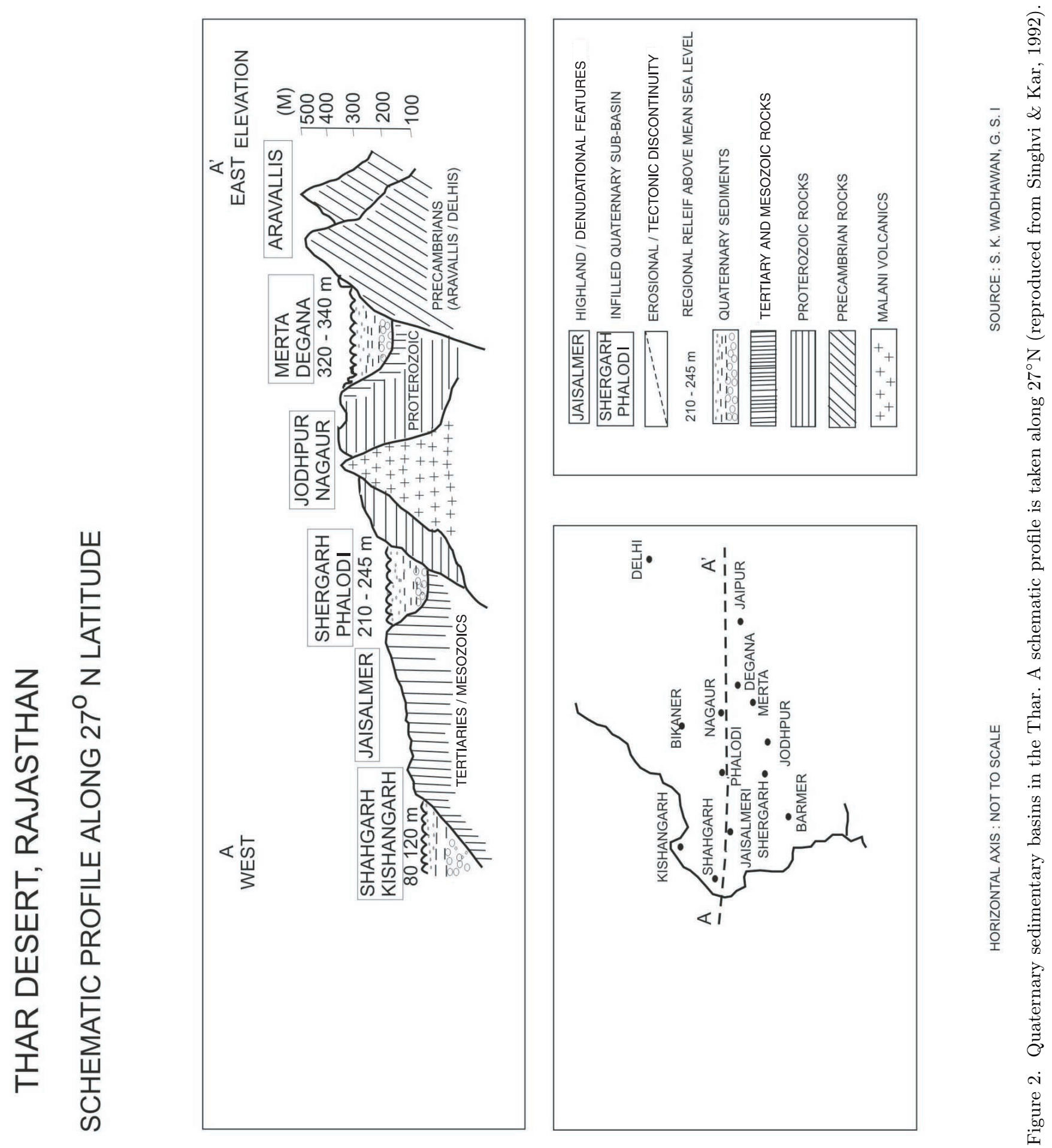


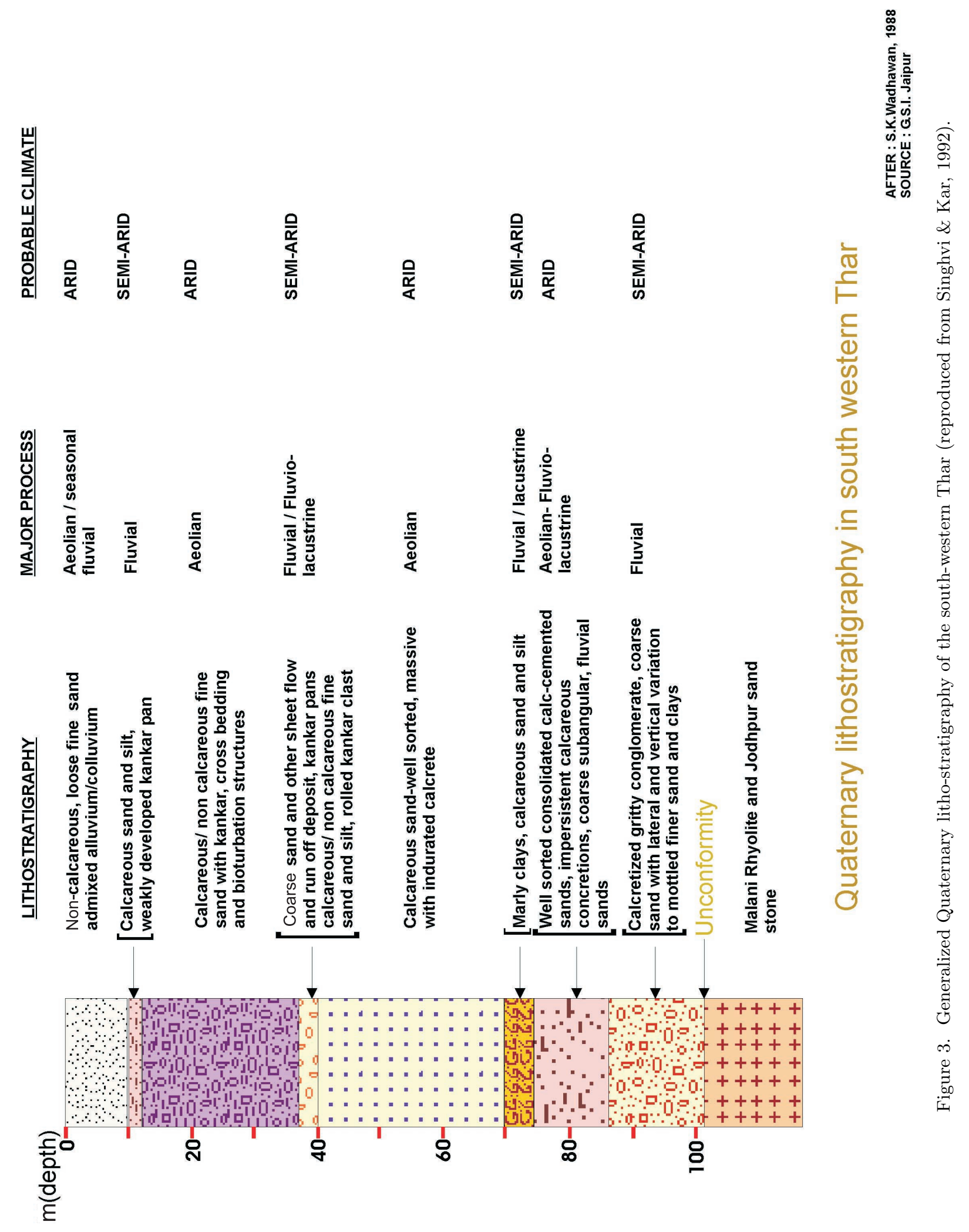


Table 1. Wind erosion index (March - July) for the meteorological stations in Thar desert.

\begin{tabular}{cll}
\hline $\begin{array}{c}\text { Wind erosion } \\
\text { index (\%) }\end{array}$ & Erosion category & \multicolumn{1}{c}{ Station } \\
\hline 480 and above & Extremely high & Jaisalmer, Chhor \\
\hline $120-479$ & Very high & Phalodi \\
\hline $60-119$ & High & - \\
\hline $30-59$ & Moderate & $\begin{array}{l}\text { Bikaner, Jodhpur, } \\
\text { Barmer, Pachpadra, } \\
\text { Hyderabad, Sukkur, } \\
\text { Khanpur }\end{array}$ \\
& & $\begin{array}{l}\text { Ganganagar, Churu, } \\
\text { Nagaur, Jaipur, } \\
\text { Badin }\end{array}$ \\
\hline $15-29$ & Low & $\begin{array}{l}\text { Hisar, Sikar, Sambhar, } \\
\text { Ajmer, Erinpura, } \\
\text { Bahawalpur }\end{array}$ \\
\hline $1-14$ & Very low &
\end{tabular}

desert, including the compound parabolic dunes, longitudinal (linear) dunes, transverse dunes, linked star dunes, a variety of network dunes, major obstacle dunes (along the hill slopes), barchans, barchanoids and megabarchanoids, and the low sand streaks (Pandey et al 1964; Singh
1982; Kar 1993a, 1996; figure 6). A perceptible change in the characters of sand dunes can be seen in a westward traverse from Aravalli foothills. Sand dunes in the easternmost part are vegetated, or cultivated almost near to their crests, and are partly gullied. New crescentic dunes are few, and reactivation of the high dunes is largely confined to regions proximal to major settlements. Westward the natural vegetation becomes gradually sparse, cultivation on dune slopes becomes less frequent, and reactivation of the high dunes more recurrent. The frequency of crescentic bedforms increases to the west of 120 contour of wind erosion index, and grasses and small shrubs start dominating the noncrescentic dune slopes. Higher dunes are draped with a thick apron of loose sand.

The above variations in dune characteristics, as well as variations in a number of other morphological features of the dunes led Pandey et al (1964) to differentiate between dunes of 'the old system' and 'the new system'. Dunes of 'the old system' are mostly the high linear, parabolic, transverse, star, network and major obstacle dunes, and are the products of past changes in climate. These dunes are usually 10 to $40 \mathrm{~m}$ high, and are now naturally stabilized with calcified roots of vegetation and other soft carbonate nodules within them, though

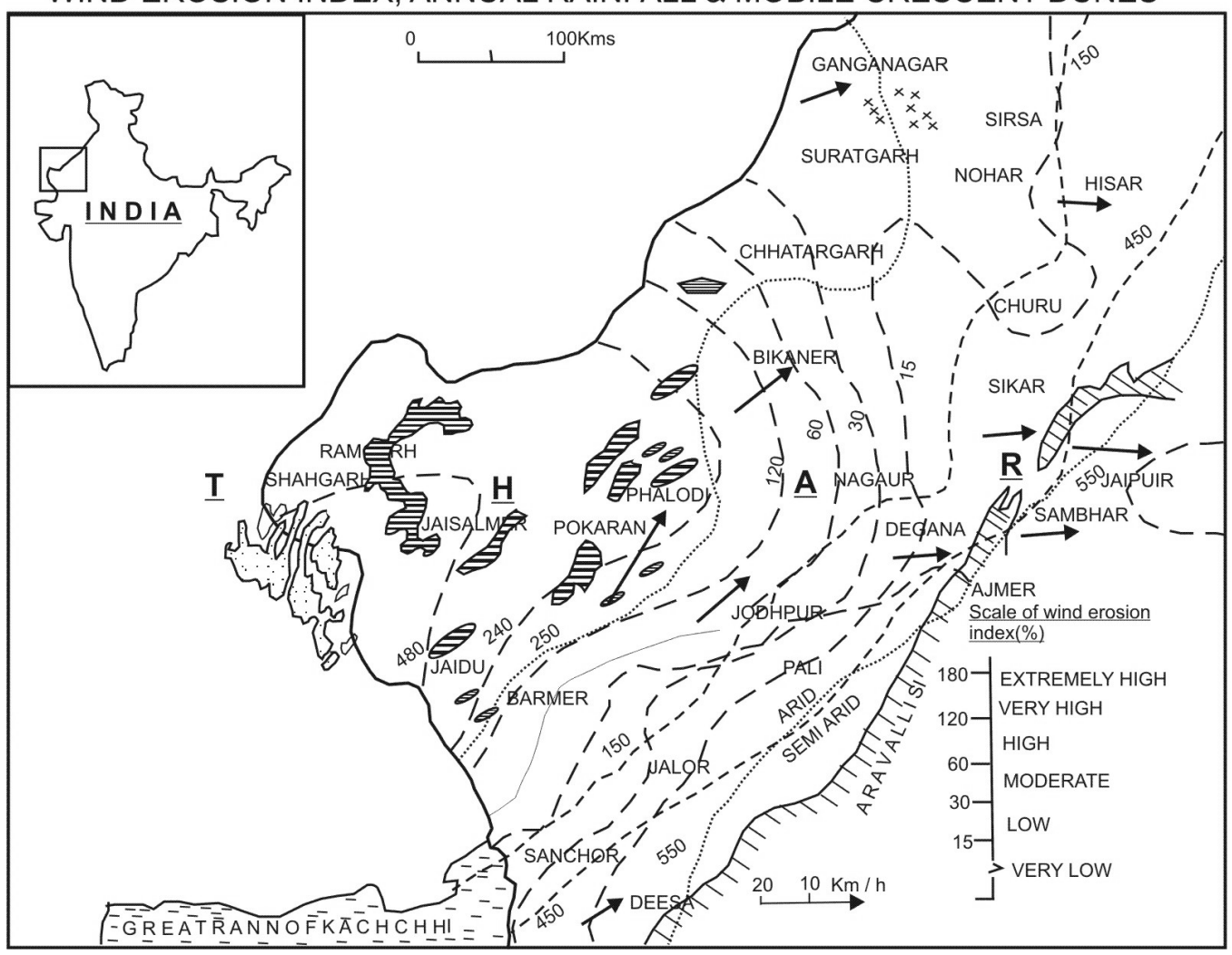

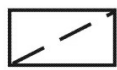

WIND EROSION INDEX(\%)

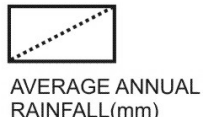
RAINFALL $(\mathrm{mm})$

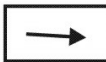

RESULTANT WIND(JUNE)

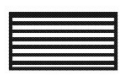

MAJOR BARCHAN AND BARCHANOID FIELDS

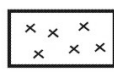

LOCALIZED BARCHANS

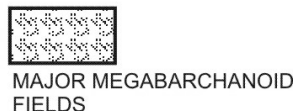

Figure 4. Spatial pattern of wind erosion index in the Thar desert (modified from Kar 1998). 


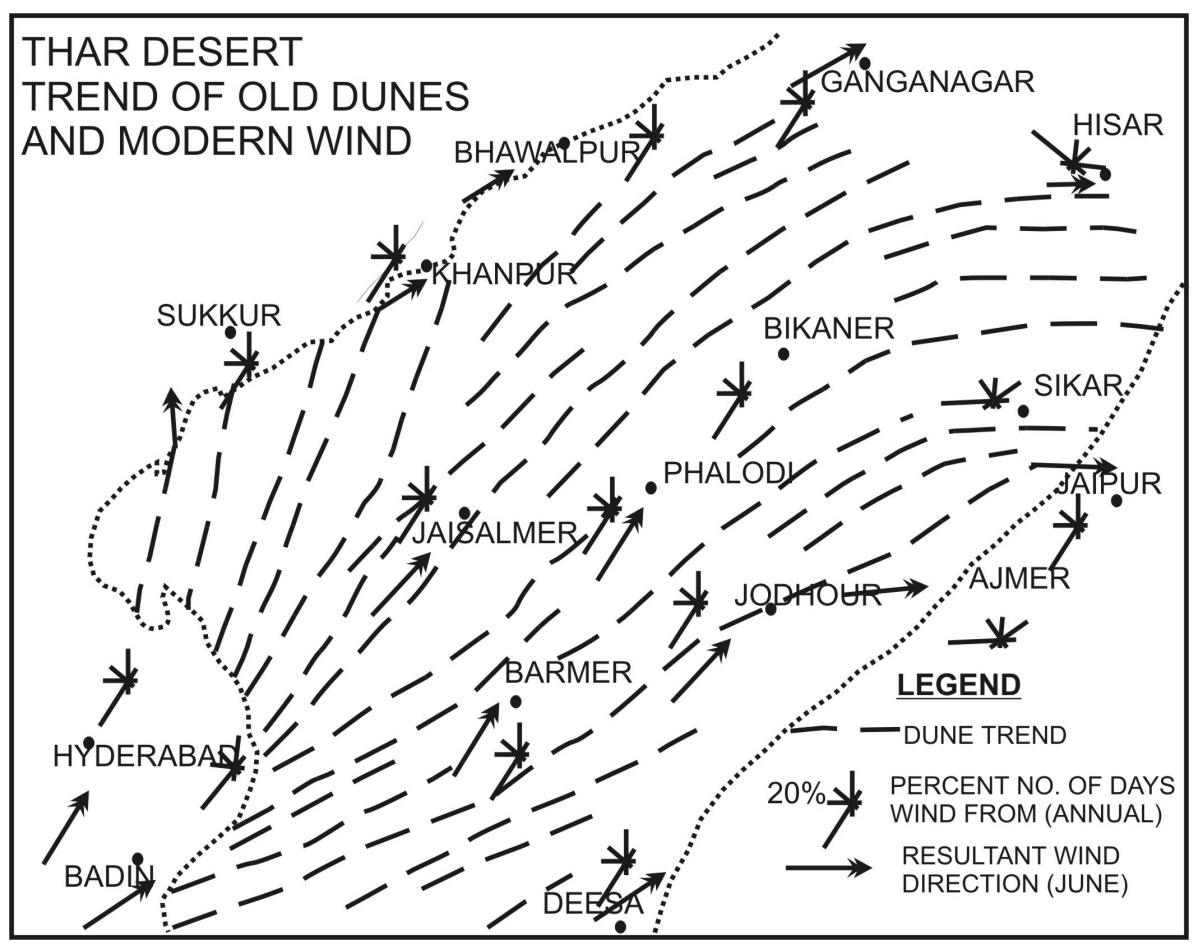

Figure 5. Dune trends and modern winds in Thar (after Kar 1993a).

many have a reactivated crest and flanks. Traces of a weak pedogenesis can sometimes be noticed in the upper 1-2 $\mathrm{m}$ of the dune profiles. Since the average silt and clay content in the dunes is 10$15 \%$ of the total sediment weight, moisture-holding capacity of the dunes is high. The dunes, therefore, can sustain a good amount of natural vegetation. In contrast, the dunes of 'the new system' consist mostly of the crescentic barchans $(2-8 \mathrm{~m})$, the barchanoids $(2-15 \mathrm{~m})$ and the megabarchanoids $(20-40 \mathrm{~m})$, as well as some small dunes like the nebkhas, source bordering dunes, sand streaks, zibars, etc., which are forming under the present arid condition in the western part of the desert (Singh 1982; Wasson et al 1983; Kar 1993a, 1996, 1999).

Apart from the above two categories of dunes, a number of 'fossil' dunes occur beyond the wetter eastern margin of the Thar, especially up to Rohtak, Sultanpur, Bandikui and Lalsot in the north-east and to Idar-Langhnaj in the south. The dunes are highly stabilised, gullied and have undergone moderate pedogenesis, leading to the formation of a slightly reddish brown horizon at or near the surface (Singh 1982; Kar 1999). Presently, these areas receive more than $550 \mathrm{~mm}$ of average annual rainfall. This broad classification is almost similar to the concept of 'active', 'dormant' and 'relict' dunes, suggested by Lancaster (1995). While the active dunes are those that are being formed under the present climate, dormant dunes are the old dunes on which sand transport is now almost absent or very low, but which get periodically reactivated.

Goudie et al (1973) marked the former extent of the Thar desert on the basis of the occurrence of fossil dunes, noted that the present-day dune formation is largely limited to areas receiving $250 \mathrm{~mm}$ and less rainfall annually, and suggested that the dune-building activities have now shrunk westward from a previous drier climatic phase by $\sim 350$ kilometres. They termed this as 'dune shift' and it presented an interesting paradigm of periodic spatial shifts in dune forming climates. A similar dune shift of $1000 \mathrm{~km}$ in Sahara and $300 \mathrm{~km}$ in Arabia have been proposed (Yan and Petit-Maire 1994). Allchin et al (1978), while studying the characteristics of fossil dune profiles along the wetter margin of the Thar in Rajasthan and Gujarat, noted considerable reddening of some sand layers and suggested that this was an evidence of significantly wetter climatic phases in the past. In one of the profiles near Pushkar they noticed three major phases of dune formation ascribing it considerable antiquity.

\subsection{Sediment type and provenance}

The Thar sand dunes have mean grain sizes of 2.30 to $2.74 \phi$. Quartz is dominant and felspar is also in abundance (Singh 1982; Kar 1996, 2002; Wadhawan 1996). Nearer the hills and rocky pediments numerous small and unaltered fragments of the source rocks are mixed with the sand population. 


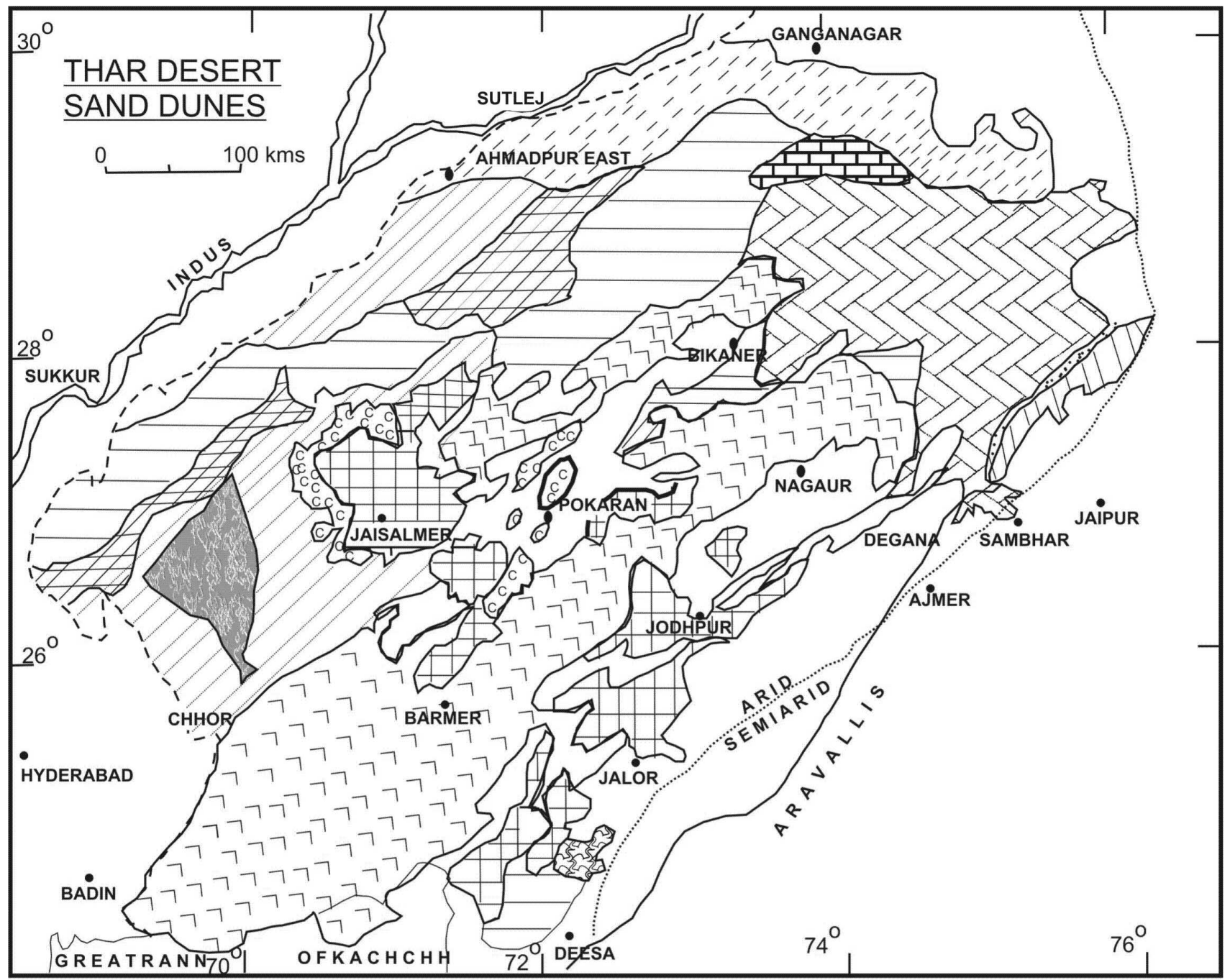

\section{LEGEND}

DOMINANTLY OLD DUNES

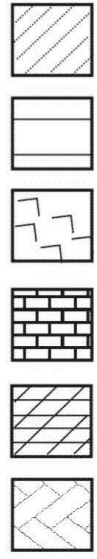

LINEAR DUNES

TRANSVERSE DUNES

PARABOLIC DUNES

STAR DUNES

NETWORK: LINEAR DUNES WITH TRANSVERSALS

NETWORK: TRANSITIONAL PARABOLIC DUNES

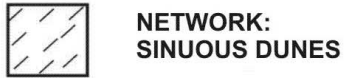

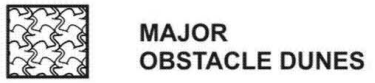

\section{NEW DUNES}

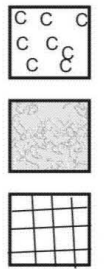

BARCHANS \& BARCHANOIDS

MEGABARCHANOIDS

SAND STREAKS AND

ZIBARS

Figure 6. Dune types in the Thar (after Kar 1996).

The other major source of sand is the alluvium and colluvium, and the pre-existing landforms. The earlier view that the Great Rann of Kachchh provided the sand is incorrect (Pandey et al 1964) as no grain-size gradation with distance is seen.
The average grain size characteristics of the major dune types in the desert are provided in table 2 . Grain size sorting usually improves as the mean size decreases, although a wider scatter is noticed at 2.20 to 2.50 phi range (Kar 1996; Wadhawan 
Table 2. Size character of sand at crest of some major dune types in Thar desert of Rajasthan.

\begin{tabular}{llccc}
\hline Dune type & Zone & Mean $(\phi)$ & Median $(\phi)$ & Sorting \\
\hline Parabolic & South & 2.82 & 2.78 & 0.360 \\
\hline West & Central & 2.62 & 2.65 & 0.436 \\
\hline Linear & East & 2.63 & 2.67 & 0.388 \\
\hline Westernmost & 2.60 & 2.64 & 0.333 \\
\hline West & 2.85 & 2.82 & 0.493 \\
\hline Transverse & East & 2.57 & 2.62 & 0.486 \\
\hline Star & West & 2.68 & 2.72 & 0.314 \\
\hline East & 2.57 & 2.62 & 0.388 \\
\hline Network & West & 2.70 & 2.71 & 0.302 \\
\hline Barchan & Northwest & 2.33 & 2.57 & 0.811 \\
\hline Barchanoid & & 2.85 & 2.87 & 0.372 \\
\hline Megabarchanoid & & 2.61 & 2.64 & 0.416 \\
\hline Obstacle dunes & & 2.30 & 2.27 & 0.582 \\
\hline & & 2.25 & 2.35 & 0.524 \\
\hline & & 2.80 & 0.548 \\
\hline & & 2.382 \\
\hline
\end{tabular}

1996). The old dune crests generally have a finer mean grain size and better sorting than the dunes with mobile crest (new dunes and old dunes with reactivated crest). This latter category of dunes has a larger difference between grain size and sorting. Interestingly dune sands have a significant quantity of foraminifera of both the benthic and planktonic kind (few thousand/g, size $\sim 100-450$ Micron) (Goudie and Sperling 1977; Kameswara Rao et al 1989) up to $800 \mathrm{~km}$ inland from the Great Rann. Kameswara Rao et al (1989) identified 82 species of foraminifers, discussed their source and suggested suspension as their mode of transport.

\section{Chronology and palaeoenvironmental reconstruction}

\subsection{Chronometric methods}

\section{A. Radiocarbon dating}

Earlier studies on Thar aimed to develop chronology based on the radiocarbon dating of calcrete nodules (also called caliche). This was attempted with the consciousness of the fact that radiocarbon dates on such systems are often erroneous on account of contamination and inheritance. Given that other methods did not provide ages on such deposits, the early radiocarbon ages were useful in the sense that they did establish the fact that the aeolian sand was old, a fact that was also indicated by the presence of archaeological material, in situ in the dunes and above them. A compilation of the radiocarbon ages is provided in Appendix I.

The development of luminescence dating that enabled the determination of the time of deposition of sand provided a way to examine the aeolian dynamism with a chronometric perspective (Singhvi et al 1982; Singhvi et al 1994). We describe here the method and the procedures briefly for the sake of completeness.

\section{B. Luminescence dating}

Luminescence dating of desert sands was first developed in the context of Thar dunes (Singhvi et al 1982; 1994). The dating protocol was initially developed using thermoluminescence (TL) methods but was later adopted for optically stimulated luminescence dating (OSL). Both the methods are based on similar premises and differ only in a minor detail of excitation procedure. The methods rely on the fact that natural minerals such as quartz and felspars serve as radiation microdosimeters of the natural radiation environment arising from the decay of natural radioactivity viz., uranium, thorium and potassium along with a minor contribution from cosmic rays. This irradiation leads to storage of energy in these crystals and some of this energy is released in the form of luminescence, when the mineral is either 
heated (TL) or stimulated optically (OSL). The luminescence induction is cumulative, such that the intensity of stimulated light is proportional to radiation dose, up to a saturation value. Minerals lose their stored geological luminescence during the pre-burial weathering and transport via photobleaching by daylight. The reduction occurs in a short duration and depends upon the flux and spectrum of daylight. Thus, at the time of burial the sediments have a near-zero luminescence level and, on burial a fresh acquisition starts due to irradiation from ambient radioactivity. This continues until excavation. As the resetting of clock occurs in a short duration, each episode of reworking basically resets the luminescence clock and hence in the case of multiple reworked sediments only the most recent burial event is recorded. Luminescence acquired during other burial episodes are reset. With the progress of experimental capabilities, the present study used all the variants of luminescence techniques, ranging from TL to Optical methods (the infrared stimulated luminescence, IRSL, and the blue-green or green stimulated luminescence, BGSL/GLSL). It is noteworthy that IRSL is shown only by feldspar, while BGSL is provided by both quartz and feldspar. Suitable mineral separation techniques enable mineral-specific BGSL, and this was done in the present study. Comparison of ages from different methodologies in a few select cases indicted that the ages were in general concordant for the aeolian sands and indicated that the ages were in general robust. This implied that while the thermoluminescence method was robust for dating aeolian sands, the optical methods and their recent variants like the single aliquot regeneration methods, provide better precision.

Typically luminescence was measured in a standard TL-OSL reader that provided for stimulation systems for both TL and OSL, measurement system comprising a photon-counting apparatus, appropriately configured to look at the desired emission spectrum of the luminescence, and a beta source for irradiation. Other methodological details are provided in Singhvi and Krbetschek (1996). Suffice here to say that with appropriate calibration using a beta source, the luminescence intensity can be converted to equivalent radiation units (called the palaeodose, $D_{e}$ ). Analysis of the bulk sediment for its radioactivity viz., ${ }^{238} U,{ }^{232} \mathrm{Th}$ and ${ }^{40} K$ provides the annual radiation dose. In the present case, thick source $\mathrm{ZnS}(\mathrm{Ag}$ ) alpha-counting technique was used for the estimation of elemental concentration of uranium and thorium. NaI (Tl) gamma spectrometry was used for the estimation of potassium concentration. Typically $5 \%$ water content was assumed in the calculation of annual dose rate.
Methodologically, some of the studies on IRSL indicate that this signal fades with time and as a consequence the IRSL ages may be underestimated. A limited comparison with quartz ages indicated that the effect was unlikely to be serious in our studies and the inferences drawn were not to be affected by such an effect. Typically such an underestimation may imply a systematic error of $<5 \%$ for a sample of $\sim 20$ ka age.

\subsection{Chronometric results and palaeoenvironment}

Sedimentary records from several, up to $20 \mathrm{~m}$ deep profiles in the sandy plains and sand dunes within and outside the desert were analysed for granulometry, sedimentology, geo-archaeology and absolute dating through luminescence techniques (TL, IRSL, BGSL and GLSL). The luminescence chronometry of aeolian sand first demonstrated by Singhvi et al (1982), has now matured as a reliable chronometric tool (Singhvi and Krbetschek 1996). The sites that were investigated are shown in figure 7. It may be appropriate here to clarify that the ages based on luminescence are the burial ages and consequently these reflect the time and climate that facilitated dune accretion. The luminescence dates are summarized in Appendix II.

In almost all the sections that were examined, visible bedding plane records of aeolian environment were better preserved in the upper few meters of the sand stratigraphy, mostly as cross-bedded units, but also as some thin planar beds, or as disturbed layers due to human activities. The preservation of bedding plane records is better in the more dry western part. Deeper down the profiles the old bedding plane records are obliterated due to leaching of the carbonates and finer particles that tend to homogenize the sand strata. Some of the deep sequences also revealed layers of colluvium or other fluvially transported sediments, which suggested changes in the dominant sedimentation processes at those sites (figure 8). Subtle variations in sediment compaction, grain size characteristics, carbonate concentration, colour, etc., could also be noticed down the profiles (figure 9). These suggested different periods of sand accumulation, followed by periods of sand stabilization.

\subsection{The Pleistocene record}

The earliest known record of aeolian sedimentation in the Thar desert is about $200 \mathrm{ka}$, as derived from the finding of middle and lower Palaeolithic tools at 14-16 $\mathrm{m}$ depth of a hill-bordering linear dune near Didwana in the eastern part of the desert (Wasson et al 1983; Mishra and Rajaguru 1994), as well as uncorrected $\mathrm{U} / \mathrm{Th}$ series ages on carbonates and 


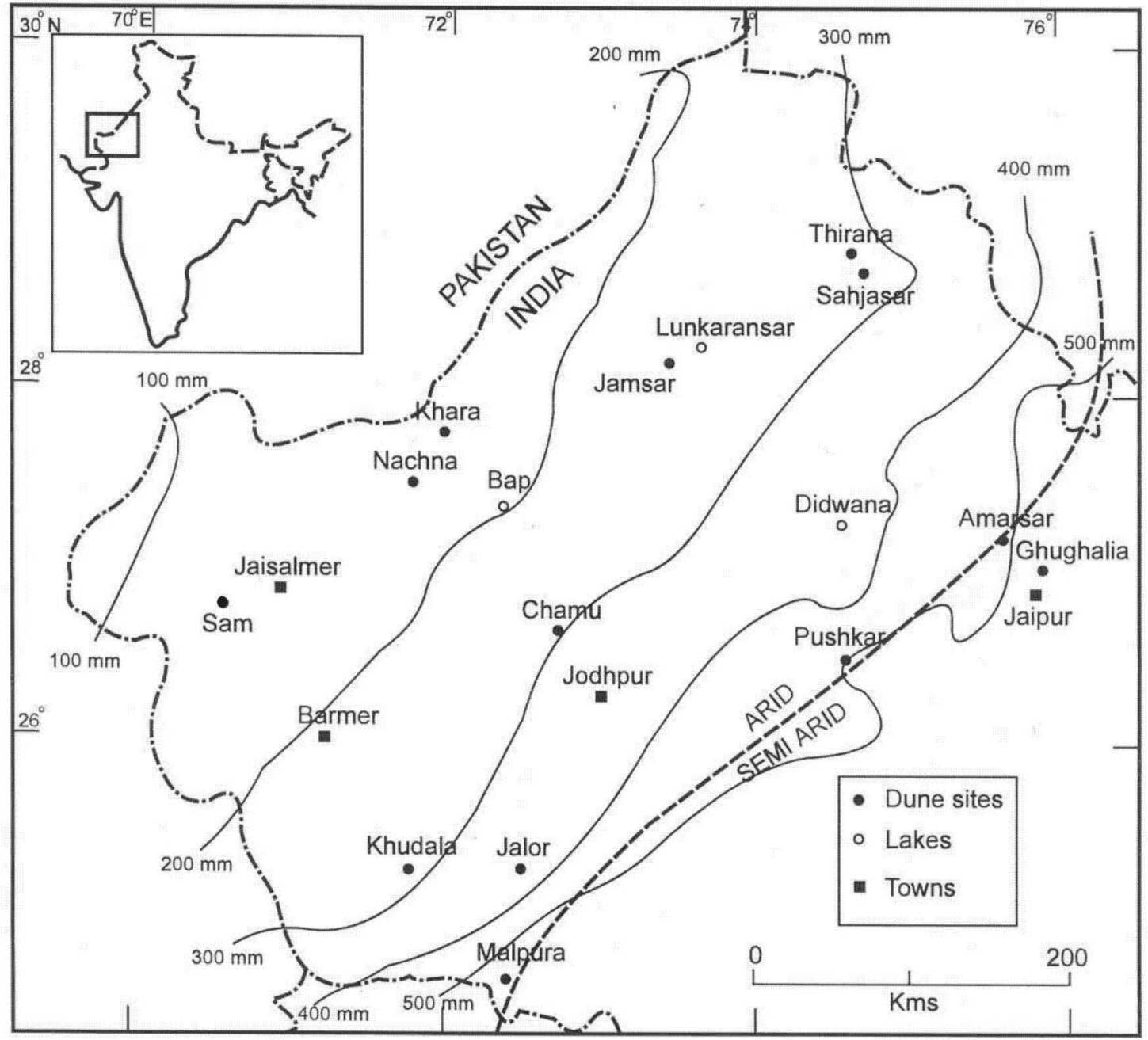

Figure 7. Location of sites. Present day boundary between arid and semi arid zones is also marked.

TL dating of host sand (Raghavan et al 1989). Considering that the aeolian accumulation continued along the fringe of a hill, Kar (1990b; 1999) postulated that horseshoe vortices, which create the hillbordering linear dunes under present environment, were active during the earlier phases of dune building also, and that the bedform was a linear dune all through its development stages. In almost all the deep sequences studied, a date of $\sim 100-115 \mathrm{ka}$ in aeolian sand at a depth of $8-15 \mathrm{~m}$ was encountered, where the material was brownish medium to fine sand with defused carbonate nodules and had typically segregated aeolian lumps (Kar et al 1998b, 2001; Chougaonkar et al 1999). At Khudala in the southern part of the desert the base of a $15 \mathrm{~m}$ high cliff on the bank of the present-day Luni river revealed medium to fine aeolian sand with poor sorting possibly due to proximal transport. This suggested deposition as a sand sheet under more arid climate (Kar et al 2001; figure 10). At Chamu (central Thar) and Amarpura (eastern fringe of the
Thar) the sand is well sorted and points to deposition as dunes.

The data gathered so far suggests that around $100 \mathrm{ka}$ a regionally extensive more arid climate prevailed over Rajasthan and surrounding areas. Depending on the topographical situation, sand supply and other environmental factors, the deposition at different sites during the period was either as sand sheets, low sandy undulations or sand dunes of different kinds. This continued to be the case in every other aeolian depositional phases also, that followed it and preceded it, and questions the suggestion that the first phase of dune formation involved the development of parabolic dunes (Bikaner formation), followed by a phase of transverse dune formation (Churu formation), and then the formation of linear dunes, sand sheets and low sand mounds (Sambhar formation; Sundaram et al 1996). Neither an argument based on process-form interactions (Kar 1987, 1993a,b), nor the dating of the dunes (Chawla et al 1992, Singhvi and Kar 


\section{CHAMU}

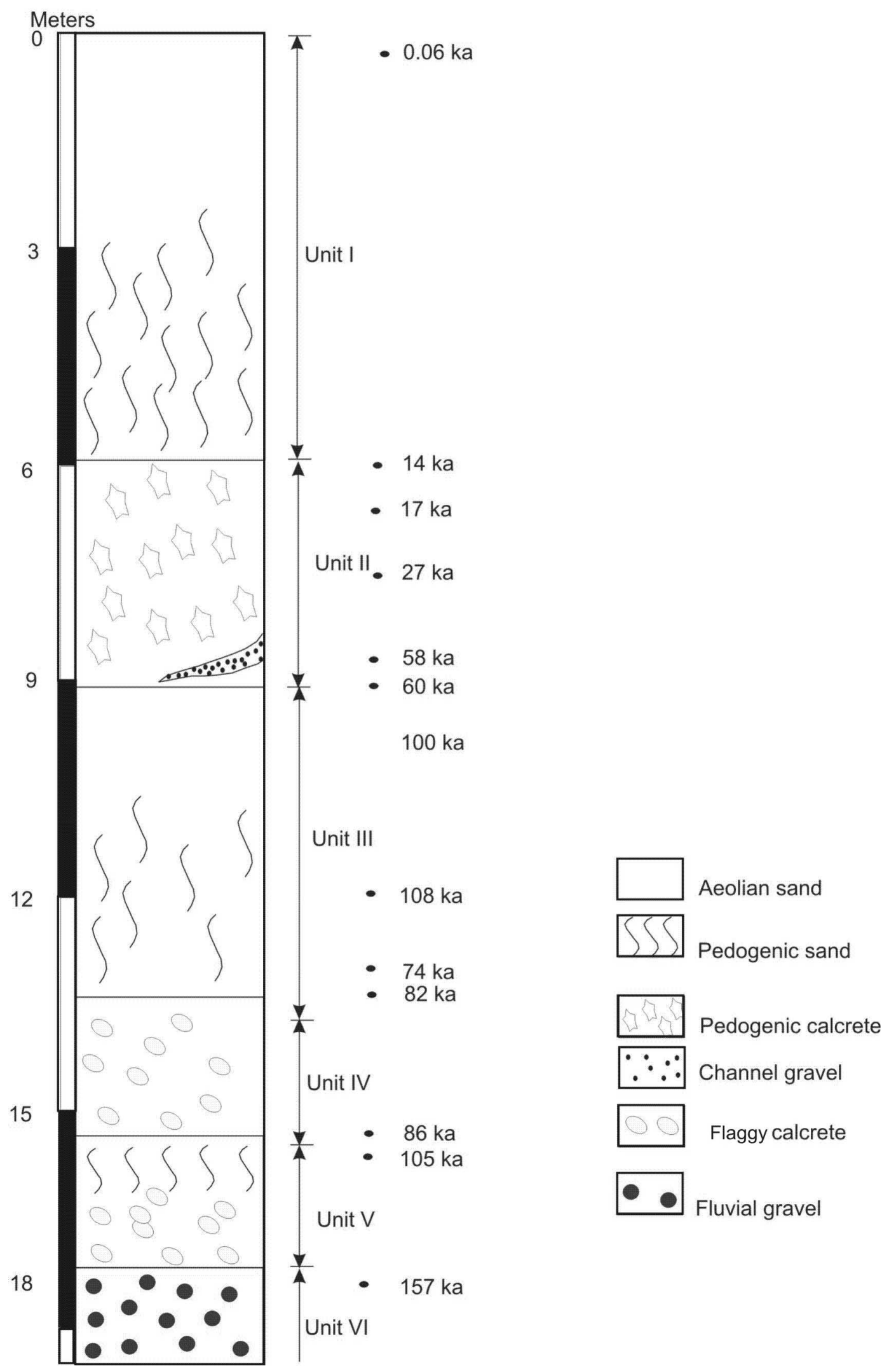

Figure 8. Deep aeolian sand profile at Chamu to indicate the antiquity, the periods of dune accretion and the periods of quiescence in the desert. 


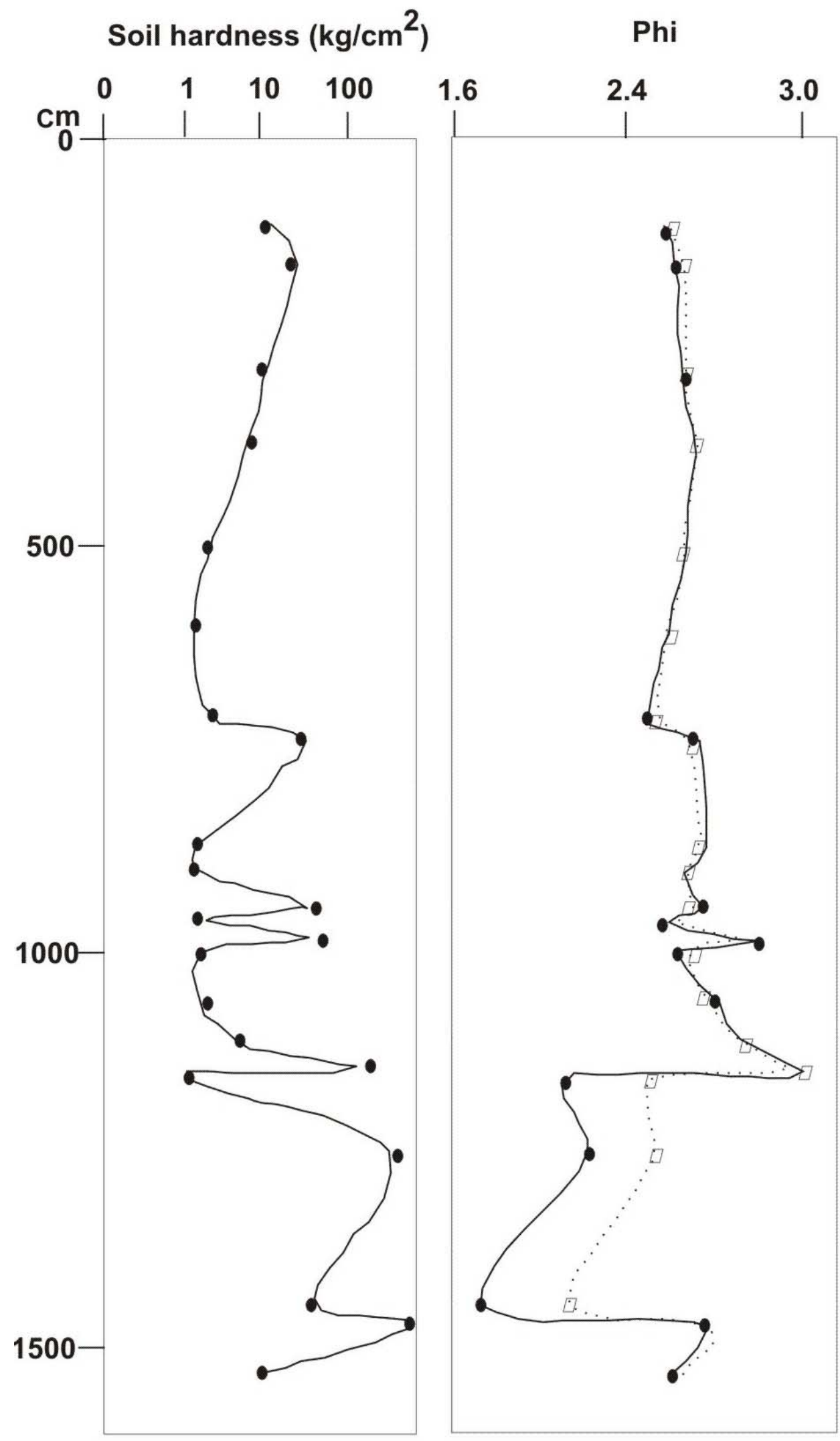

Dune profile and grain size variation indicating episodes of dune accretion and periods of soil formation.

Figure 9. Sediment characteristics of the representative dune profiles at Khudala (modified after Kar et al 2001). In phi measurement solid line shows mean and dotted line median. 


\section{KHUDALA}

LITHOLOGY
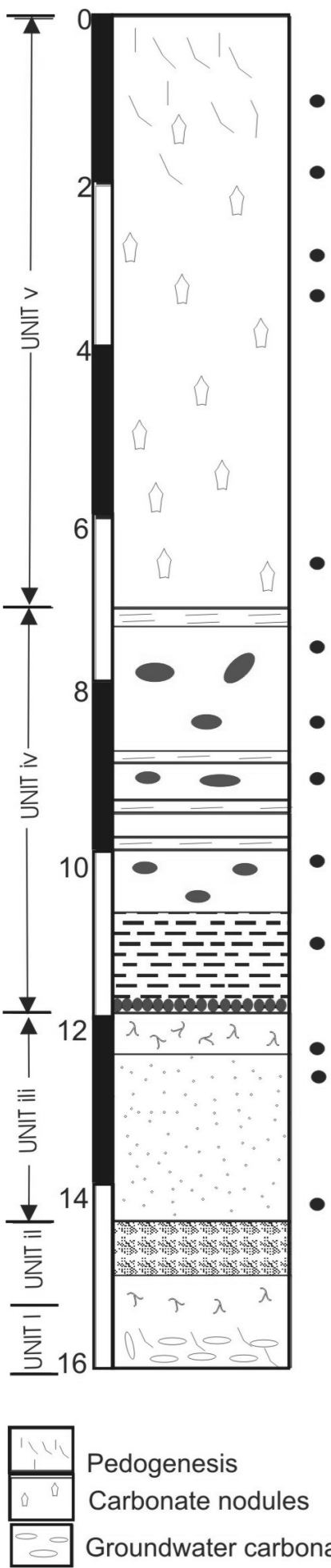

Pedogenesis

Carbonate nodules

Groundwater carbonate
AGES(ka)

GLSL

$3.1 \pm 0.8$

$8.1 \pm 0.9$

$10.5 \pm 3.9$

$9.5 \pm 4.0$

$9.5 \pm 1.1$

$11.7 \pm 4.0$

$23.8 \pm 5.5$

$52 \pm 21.8$

$86.3 \pm 28.5$

$>100 \mathrm{ka}$

\section{REGIME ENVIRONMENT}

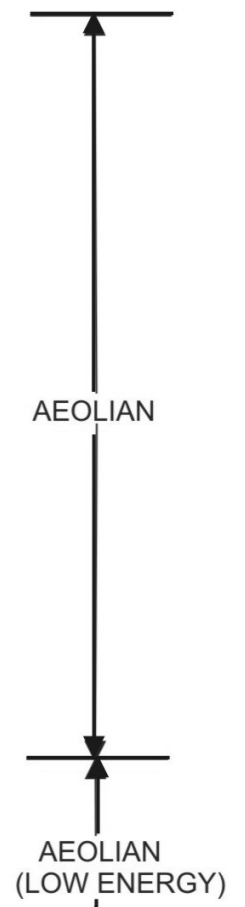

HARAPPAN DECLINE

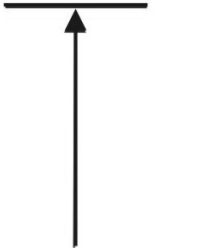

NODULES

OF HOLOCENE

OPTIMUM

PERIOD

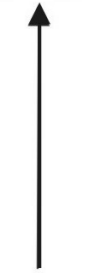

MONSOON

(LOW ENERGY)

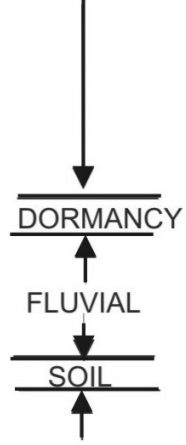

FLUVIAL

(SAND SHEET +

SHEET FLOOD)
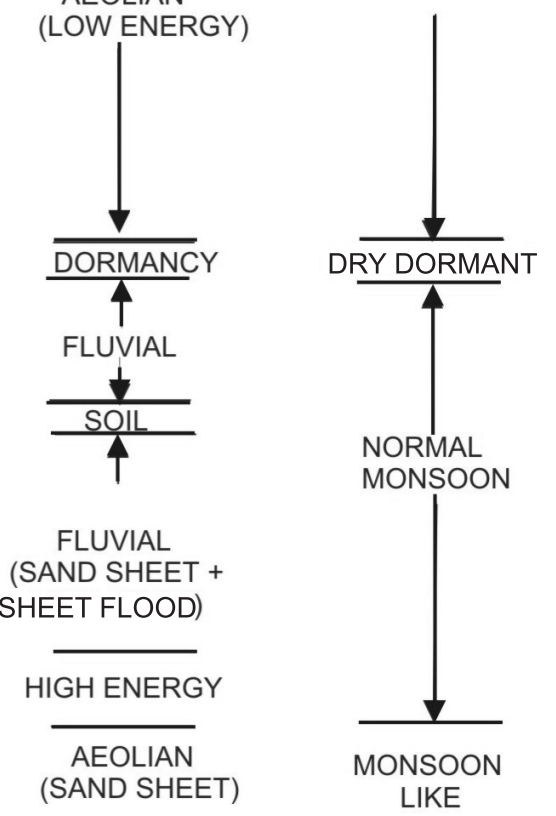

MONSOON

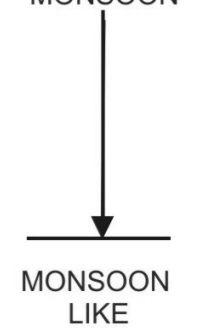

Figure 10. Lithological, chronometric and climatic interpretation of a typical aeolian-fluvial sequence in the Thar desert (modified after Kar et al 2001).

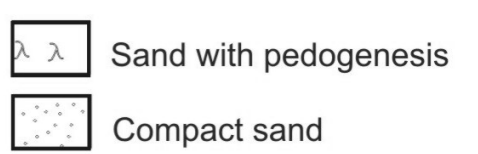


1992) support the thinking that the three major dune types in the desert, the parabolic, transverse and linear, were formed in three different periods. Thus, no temporal hierarchy in the formation of these dune types existed (Kar 1997). The controversy was triggered by a suggestion by Verstappen (1968) that the linear dunes here (seif, according to him) might have developed due to blowing away of the nose of parabolic dunes. The idea was then taken up by later researchers, but was not validated by any study. The linear dunes in the Thar desert are not the 'seifs', and occur in a unidirectional wind field. Kar (1987, 1990a, 1996) discussed the mechanism by which a spatially changing wind environment could lead to the development of linear and parabolic dunes during the same period. Accurate measurements of a parabolic dune by Kar et al (1998c), using a pair of satellite-guided Global Positioning Systems, revealed that the nosal part of the parabolic dune contains more than 35 per cent sand (by volume). Kar (1996) suggested that during strong wind through the corridor between two arms of a parabolic dune, sand blown from the upwind side and crest of the nose either avalanches along the slip face or is dropped in front of the earlier nose, either as another curved segment, or as low linear arms of a new parabolic bedform downwind. This is because of the pressure difference between the constricted corridor and the open space downwind of the nosal part (Kar 1996). In other words, all other factors remaining the same, aeolian erosion in a parabolic dunefield will lead to the gradual formation of a new set of parabolic bedforms downwind, as was monitored through remote sensing (Kar 1993a).

Distinct lithic, flaggy calcrete bands in the lower part of the excavated sand profiles at Amarpura, Chamu and Khudala, especially in the $>100 \mathrm{ka}$ aeolian sand unit, were seen. This, perhaps, suggests that some time after the aeolian deposition, rainfall and terrain conditions in the area were favourable for the development of a marshy tract. High evapotranspiration rates and possible ground water enrichment of the sites resulted in gradual development of lithic calcrete bands within the sand deposit. Jain et al (1999) found a thick deposit of channel gravel on the bank of the Luni river, dated to $\sim 90 \mathrm{ka}$, and suggested that a highenergy fluvial regime was established in the region after the major dry phase. Previous to this fluvial regime the region experienced a major wetter interlude of sustained nature at about $125 \mathrm{ka}$ when a major interglacial climate prevailed over the earth.

At most sites the aeolian units from $\sim 75 \mathrm{ka}$ onwards are characterised by extensive nodular calcrete development, where the soluble carbonate content varies from 40 to 55 per cent, and residual fine to medium sand the rest (Dhir 1995). Although the carbonate nodules are randomly distributed within the sand and occur in dense packing in the lower part of any unit, field observations by Kar (1994) on wind-assisted rolls of the nodules on old dune surfaces, especially during strong sandstorms in the high wind energy zone, and surface concentration of the rolled carbonate nodules suggest that banding in some horizons could be due to strong deflation over a dune/sandy plain surface, which periodically exposed a layer of nodules to the surface, and then rolled and rearranged the nodules as an armoured surface (Kar 1994; 1996).

Andrews et al (1998) studied the oxygen stable isotopic composition of nodular pedogenic calcretes within four aeolian units of an aeolio-colluvial sequence near Shergarh that were formed between 70 and $25 \mathrm{ka}$, and were separated by colluvium, which consisted of rhyolite clasts from the nearest hill and rolled calcretes (figure 11). It revealed that during 70-60 ka, when the lowermost calcretebearing aeolian unit was being formed, and during 25-30 ka when the uppermost calcrete-bearing aeolian unit was being constructed, winter rain was dominant, and the climate was more arid. During the deposition of the other two aeolian units SW monsoon rains prevailed, and the climate was less harsh.

Aeolian units dated to $\sim 75, \sim 55$ and $25-30 \mathrm{ka}$ were noticed within most of the deep sandy profiles (Kar et al 1998a; 2001). A prolonged wet phase in the intervening period resulted in landscape stability across the desert and its margin from Punjab and Haryana in the north to Gujarat in the south. Tandon et al $(1996 ; 1999)$ reported major fluvial aggradation in the Sabarmati and Mahi basins of Gujarat between 40 and $60 \mathrm{ka}$, as well as pedogenesis across the plains of north Gujarat and south Rajasthan, as evidenced by a reddened palaeosol on aeolian fine sand deposits. Using the terminology of Kocurek $(1988,1991)$ this regionally extensive surface can be designated as a Super Surface that cuts across bounding surfaces of different orders. The pedogenesis is strong in the Gujarat plains, but weaker in south Rajasthan (Kar et al 2001; Juyal et al 2003).

In the semi-arid east Rajasthan (average present annual rainfall 550-700 $\mathrm{mm}$ ), occasional narrow silt-and-clay-rich horizons within the aeolian sand units, with a mottled greyish brown appearance and few near-vertical streaks, occurred. A weakly developed pedality, and a decreasing content of carbonate nodules are the other characteristics of these horizons. According to Kar (1999), the possible explanation for the occurrence of these horizons is high rainfall during a sustained more humid phase following a major dry phase. Such condi- 


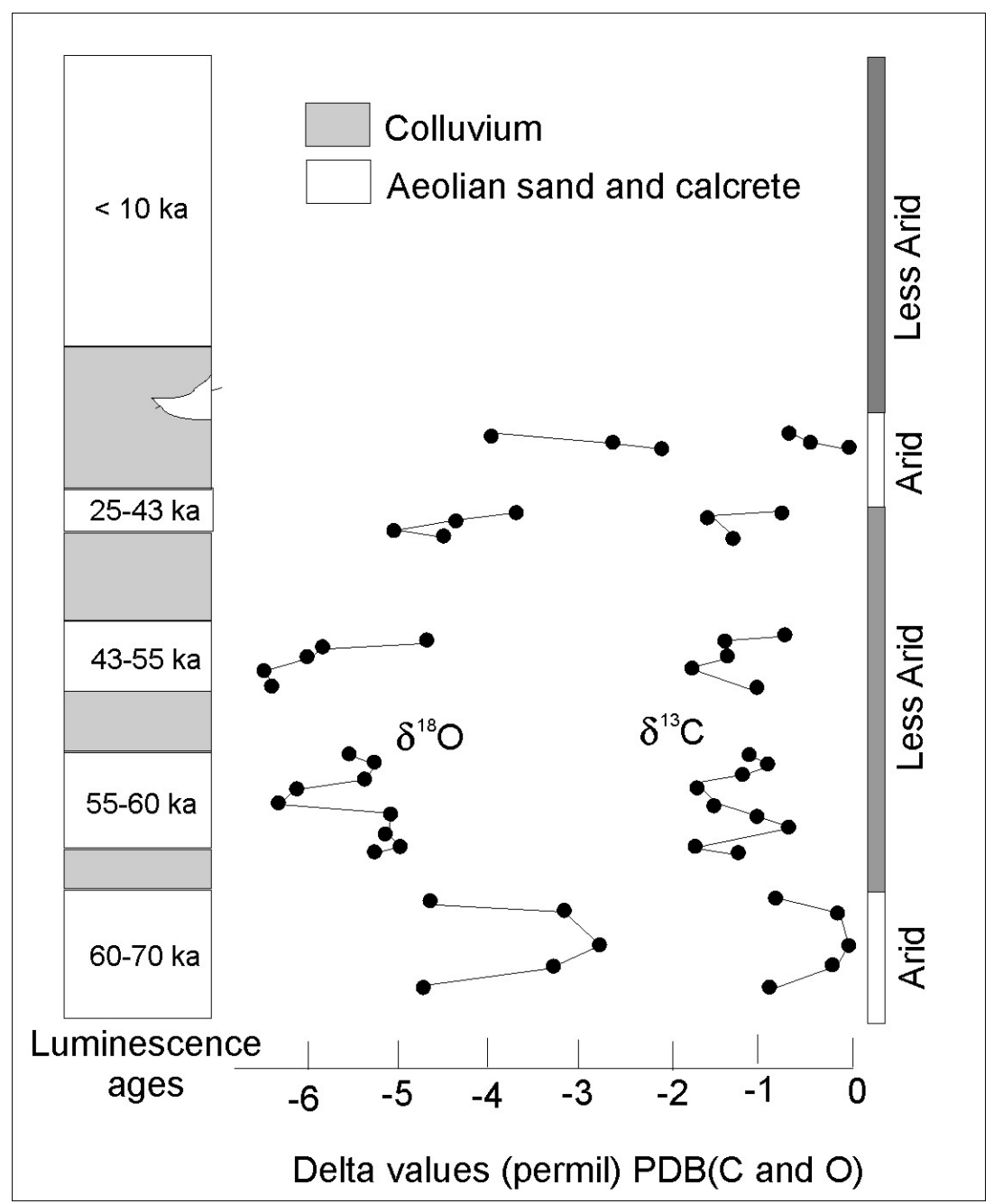

Figure 11. Rainfall reconstruction from deep profiles in the central Thar (reproduced from Andrews et al 1998 with permission from Quaternary Research).

tions favoured acidification and decalcification of an aeolian fine sand-dominated unit, followed by gradual down-washing of the silt and clay particles. These formed an illuviated horizon. Occasional dust transport from the shrunken desert of the time could be another major source of the silt.

Chronologically, the major period of aeolian sand accumulation after the depositional phase of 30 to $25 \mathrm{ka}$, was between 16 and $7 \mathrm{ka}$. The period in between the two sand accumulation phases saw a major dry phase, known as the Last Glacial Maximum (LGM), which has been dated to 24.5-18.0 ka (Sirocko 1996). Contrary to the popular belief that LGM was a period of strong dune-building activity in the desert due to lowered sea level and overall aridity that facilitated aeolian sand migration, evidence of significant sand accumulation during the LGM was not found. Evidence from Khudala, and the overall absence of any age corresponding to the last glacial epoch, suggest that during LGM, both the summer and winter winds did not have sufficient strength to build the dunes. The westerly and north-westerly winds however contributed somewhat higher rainfall, as revealed from isotope analysis of the carbonate nodules (Andrews et al 1998). The SW monsoon wind that built the dunes in the past, was very subdued during the LGM and implied dormancy of aeolian aggradation. Studies at Khudala also indicated the absence of fluvial aggradation, leading to the suggestion that during the LGM, geomorphic processes, both aeolian and fluvial, were dormant to the point of being inactive due to a substantially weakened SW monsoon. While it can be argued that the aeolian processes post-LGM could have obliterated the LGM record the consistency of the ages throughout the region and the uniform absence of LGM ages preclude this. It follows that large-scale aeolian dynamism did not coincide with LGM in the Thar, and implicitly suggests that the desert albedo changes on account of desert expansion were also not synchronous. On a regional to global 
scale this implies that perhaps the desert albedo changes on account of an assumed synchronicity with glacial climate may have been grossly overestimated.

Studies on deep oceanic cores from the Arabian Sea revealed that strong monsoon circulation started in the region from $\sim 14$ ka (Sirocko 1994, 1996; Overpeck et al 1996; Zonneveld et al 1997; Schulz et al 1998). These studies also noted that the periods of sustained higher rainfall lagged the inception of higher wind speed by years or centuries. This is possibly why we get after the LGM a higher sand accretion in many sites during 14$10 \mathrm{ka}$. It can therefore be suggested that the aeolian processes in the Thar received a small 'window of opportunity' in the time lag between the initiation of strong monsoon wind and the arrival of high monsoon rainfall, and exploited this opportunity for enhanced sand accumulation. The terminal Pleistocene, when high amplitude changes in monsoon events took place, saw frequent repetition of aeolian and fluvial beds in some of our aeolian sections, notably at Khudala where the beds were dated to $\sim 11-13 \mathrm{ka}$ (Kar et al 2001). This period, known as the Younger Dryas event, is globally known for cooler climatic excursion and significantly higher winter rainfall. Analysis of sediments from Didwana salt lake also revealed fluctuating saline to deep fresh water conditions during this period (Singh et al 1990). This has been the first evidence of Younger Dryas event from India. Figure 12 provides our reconstruction of the fossil extent of the Thar desert at $16 \mathrm{ka}$ and $5 \mathrm{ka}$.

\subsection{The Holocene record}

There is no distinguishable change in the aeolian record that indicates initiation of the Holocene by way of a marker horizon. The SW monsoon wind continued to play its role in the aeolian accumulation in the region, and continued till $7 \mathrm{ka}$, but possibly with less vigour. Between 7 and 6 ka large parts of the region experienced extended duration of higher monsoon and winter rainfall. This stabilised the sandy landscape and facilitated formation of a weakly developed palaeosol horizon, or a layer of relatively coarser sand concentration. The period around $\sim 6$ ka was most humid in the desert during the Holocene. All the major saline lakes in the desert turned into perennial lakes. Consequently they received higher amounts of silt-clay deposition (Singh et al 1974, 1990; Kajale and Deotare 1997; this issue). The aeolian landscape in the westernmost part of the desert was, however, influenced for a shorter period of time by this wetter climate.

The desert experienced another phase of higher aeolian aggradation from $5 \mathrm{ka}$ onwards, and it con- tinued till $\sim 3.5 \mathrm{ka}$ (Kar et al 1998a; Thomas et al 1999). There is, however, very little trace of this event, or any other major sand accretion event subsequent to it in the dune stratigraphy to the east and south of the present eastern limit of the desert. This perhaps suggests that large-scale sand reactivation in the areas beyond the present boundary of the desert took place before the Holocene Climatic Optimum, and that the aeolian landscape in those areas attained relative stability since then. Small events during the 5.0-3.5 ka period, however, cannot be ruled out, especially in the natural corridors of sand movement through the Aravalli hill ranges. The 5.0-3.5 ka aeolian phase in the desert is matched in the oceanic records from northeastern Arabian Sea by lower precipitation and decreasing stream run-off (von Rad et al 1999). This was a phase of the reduced SW monsoon, but not comparable to any 'glacial' event. In between, the period 4.5-3.8 ka witnessed the rise and fall of Pre-Harappan and Harappan cultures, especially along the Ghaggar valley where urban settlements flourished due to the availability of water (e.g., at Kalibangan). The dune records suggest that the civilization flourished during a phase of continued aeolian activity, and not during a period of good rainfall, as is customarily believed (Thomas et al 1999). The Harappan settlements in the desert, therefore, appear to be more a case of human adaptation to declining rainfall than that of improved hydrological/precipitation events. As the aridity peaked around $3.7 \mathrm{ka}$ (noted in the lake records), the aeolian activities dwindled. The salt lake at Lunkaransar located north of Bikaner, had an inflow of water from $\sim 11 \mathrm{ka}$, but were dry by $\sim 3.6 \mathrm{ka}$ and partially recovered by $\sim 1.8 \mathrm{ka}$ (Bryson 1989). The salt lake at Bap near Phalodi in the drier western Thar was desiccated by $\sim 6 \mathrm{ka}$ (Deotare et al 1998; this volume). By contrast the salt lake at Didwana in the eastern fringe of the desert recorded a decline in rainfall at $4.2 \mathrm{ka}$ (Singh et al 1990), but continued to receive some fresh water even up to recent time. This implies a distinct spatial gradient in the century-scale SW monsoon rainfall distribution in the desert, such that the western part is visited by the rains for a shorter period and, hence, gets lesser opportunities for the stabilization of aeolian landscape. A synthesis of dune record additionally suggests an $\sim 1500$-year cycle in dune accretion. Another important aspect was that the lake hydrological changes and dune activity had some phase lags, with dune accretion preceding the lake hydrological changes by a few centuries (Thomas et al 1999; figure 13).

There was a comparative lull in aeolian activities from $\sim 3.7 \mathrm{ka}$ to $\sim 2.0 \mathrm{ka}$, after which another burst of intense aeolian activity took place. Almost 


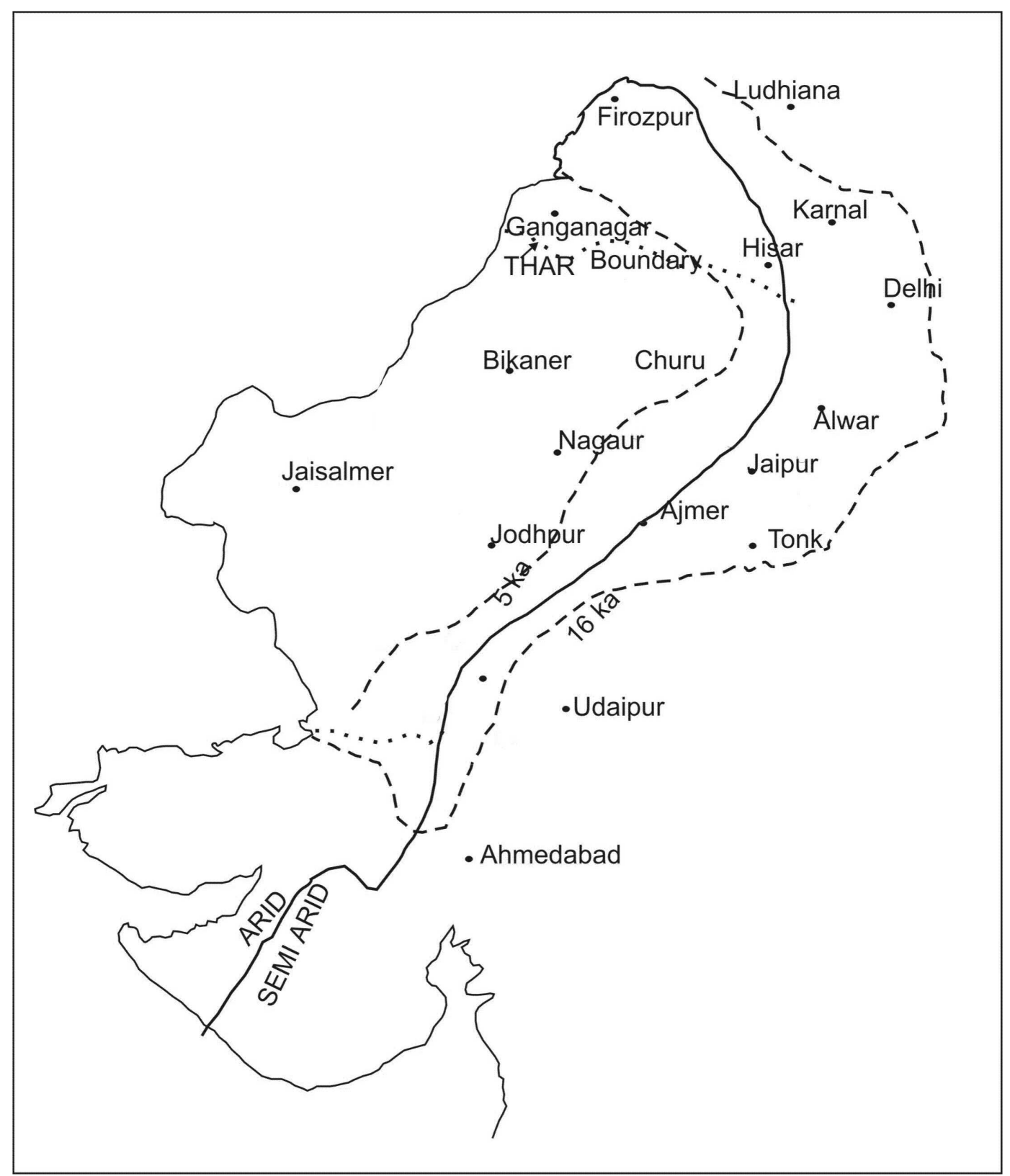

Figure 12. Reconstruction of paleo-extent of Thar desert at $16 \mathrm{ka}$ and $5 \mathrm{ka}$.

all the excavated sections in the desert experienced this phase. At Khara in the very high wind erosion zone northeast of Jaisalmer, Kar et al (1998a) measured the growth and mobility of the palaeo-crest of a transverse dune that started growing from the beginning of the Holocene (figure 14). It revealed three phases of sand accumulation from $\sim 2 \mathrm{ka}$. The first phase between 2.1 and $1.9 \mathrm{ka}$ saw a vertical accretion rate of $\sim 0.61 \mathrm{~cm}$ year $^{-1}$ and a crestal advancement of $0.87 \mathrm{~cm} \mathrm{year}^{-1}$. Between 1.8 and $0.58 \mathrm{ka}$ the accretion rate declined to $0.08 \mathrm{~cm}$ year $^{-1}$ and crestal advancement to $0.25 \mathrm{~cm}$ year $^{-1}$. The latest phase since $\sim 0.25 \mathrm{ka}$ experienced vertical accretion rate of $>2 \mathrm{~cm} \mathrm{year}^{-1}$ and a horizontal advancement rate of $1.5-9.0 \mathrm{~cm} \mathrm{year}^{-1}$. The breaks in the periods were marked by a lull in sand mobility, as well as some stability of the aeolian topography. This is reflected in grain size characteristics for the units. Although all the sand samples showed bimodality in grain size distribution, Kar et al (1998a) found that the sand population from the bottom of any unit had its main peak at the finer side of the scale, while that from near the top had its peak towards the coarser side of the scale. The trend was also reflected in the mean and median grain sizes, and in its sorting pattern. Finer mean and median grain sizes at the bottom of the units point towards the availability of sediment sizes in the dune-interdune landscape in the vicinity for the aeolian processes 


\section{Dune aggradation episodes}
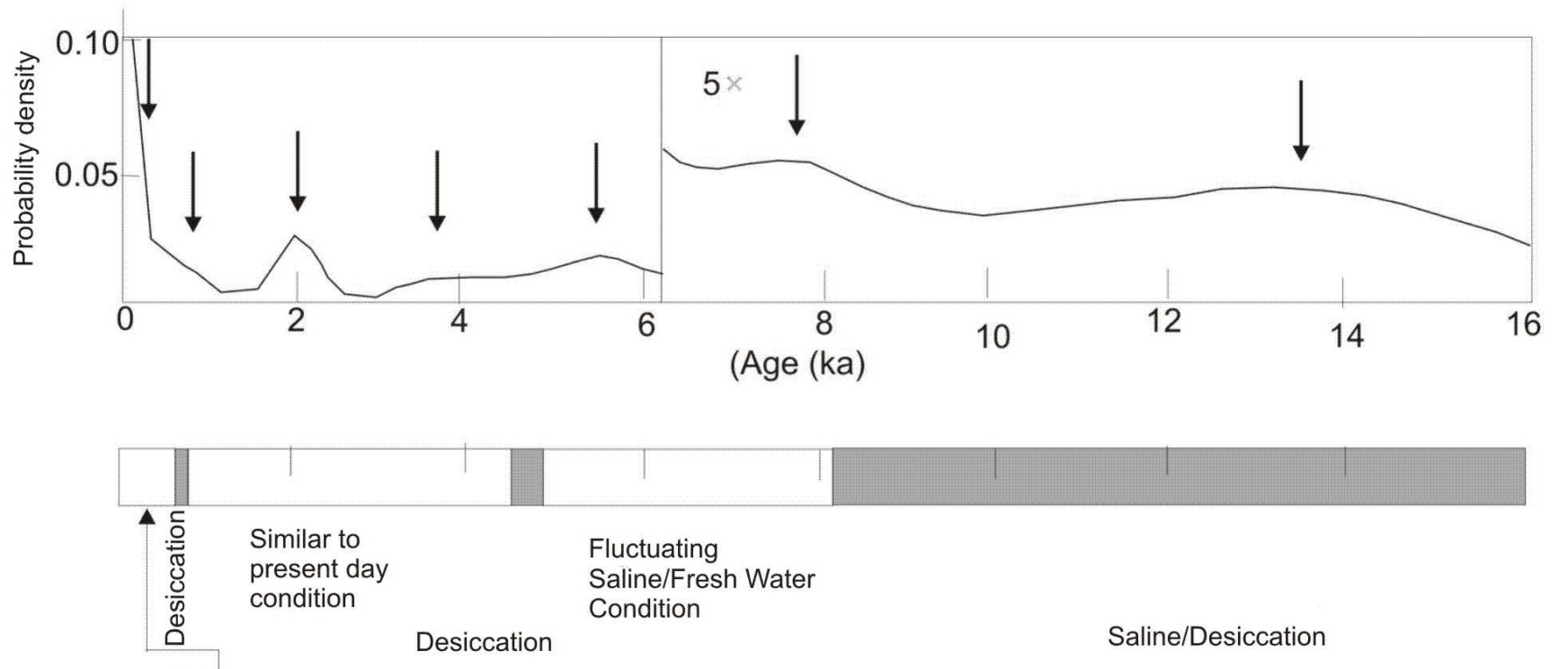

Present day condition

\section{Generalized Lake Record}

Figure 13. Dune lake correlation during the Holocene (modified after Thomas et al 1999).

to redistribute. Analysing the particle size from the crests of many old dune crests in Jaisalmer area Kar $(1987 ; 1996 ; 2002)$ noticed a similar pattern of coarser sand on the stabilised part of the crest, and finer ones on the mobile part. The coarser sizes at the top of the units reflect relative stability of the surfaces for an extended period of time when slow creeping of coarse sand and winnowing of the fines are dominant.

By about 0.6 ka the aeolian landscape in western Thar gained some stability due to a drop in the wind strength, but in the eastern part this stabilization phase started at $\sim 0.8 \mathrm{ka}$ (table 3 ). The time lag of $\sim 0.2 \mathrm{ka}$ for the start of the sand stabilization phase in the east and the west could be explained by the time taken by monsoon rainfall to establish itself from east to west. There is not yet any confirmatory lake record to strengthen the case for an increased rain event during the period, but a weakly developed palaeosol horizon in the near-surface sediments of the dunes everywhere in the desert (Thomas et al 1999), including those in the Punjab and Haryana plains (Naruse 1985) favours such an argument. Interestingly this phase also coincides with the medieval warming episode and has been documented in the slack water record of floods of river Luni during the last millennium. Thus the dune stabilization episode, palaeosol formation and enhanced flooding in Luni indicated a stronger monsoon during the medieval warming.

The next phase of aeolian activity, the most recent one, started $\sim 0.3$ ka. Globally, the period roughly between 0.6 and $0.2 \mathrm{ka}$ experienced decreased rainfall, and is known as the period of Little Ice Age. Von Rad et al (1999) noticed that the northeastern Arabian Sea off Pakistan experienced reduced varve deposition during this phase. The Little Ice Age impacted the floods in R. Luni, which had virtually no flooding in the period and imply reduced rainfall. The limited data does not permit any inference on contemporary aeolian processes in Thar, but a lull in aeolian deposition between 0.6 and $0.3 \mathrm{ka}$ could perhaps be ascribed to reduced wind. A higher-resolution lake record may help further elucidation.

The latest phase of sand mobility started from around $0.3 \mathrm{ka}$, but unlike in the previous phases this phase is marked by high human pressure on the sandy landscape, especially through cultiva- 


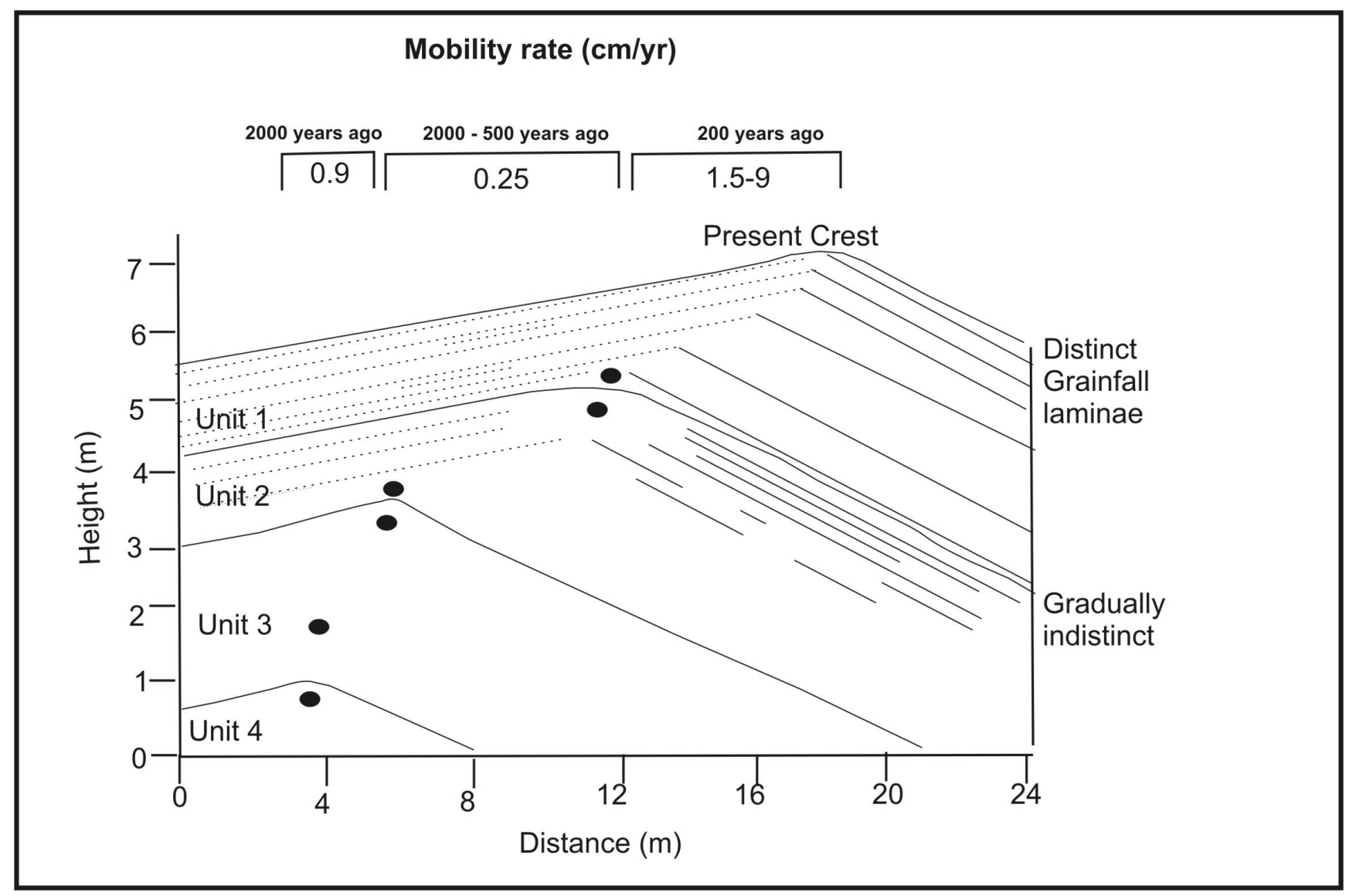

Figure 14. Dune mobility rates through time. The rates have increased in areas where the human activity has influenced the vegetation cover. Large dots show sample locations.

Table 3. Mean annual rainfall and most recent date of sand stabilization in the Thar desert. West to east transect

\begin{tabular}{lccc}
\hline Site & Location & Annual rainfall $(\mathrm{mm})$ & Stabilization date \\
\hline Khara & $27^{\circ} 11.36^{\prime} \mathrm{N} ; 75^{\circ} 57.45^{\prime} \mathrm{E}$ & 180 & $580 \pm 50$ \\
\hline Thirana & $26^{\circ} 30^{\prime} \mathrm{N} ; 74^{\circ} 36^{\prime} \mathrm{E}$ & 300 & $500 \pm 200$ \\
\hline Chamu & $26^{\circ} 40.27^{\prime} \mathrm{N} ; 72^{\circ} 35.37^{\prime} \mathrm{E}$ & 300 & $780 \pm 70$ \\
\hline Rirkala & $28^{\circ} 53.75^{\prime} \mathrm{N} ; 74^{\circ} 36.56^{\prime} \mathrm{E}$ & 400 & $800 \pm 100$ \\
\hline Budha Pushkar & $27^{\circ} 45.20^{\prime} \mathrm{N} ; 72^{\circ} 08.70^{\prime} \mathrm{E}$ & 500 & $700 \pm 60$ \\
\hline Achrol & & 600 & $800 \pm 60$ \\
\hline
\end{tabular}

\section{South east to north west transect}

\begin{tabular}{lccc}
\hline Site & Location & Annual rainfall $(\mathrm{mm})$ & Stabilization date \\
\hline Pavagarh & $23^{\circ} 26.62^{\prime} \mathrm{N} ; 72^{\circ} 28.38^{\prime} \mathrm{E}$ & 800 & 10,000 \\
\hline Mahesana & $24^{\circ} 36.91^{\prime} \mathrm{N} ; 72^{\circ} 27.70^{\prime} \mathrm{E}$ & 550 & 5000 \\
\hline Malpura & $25^{\circ} 22.30^{\prime} \mathrm{N} ; 71^{\circ} 48.61^{\prime} \mathrm{E}$ & 400 & 4000 \\
\hline Khudala & $26^{\circ} 40.27^{\prime} \mathrm{N} ; 72^{\circ} 35.37^{\prime} \mathrm{E}$ & 300 & 3000 \\
\hline Chamu & & 300 & 800 \\
\hline
\end{tabular}


tion and grazing, as well as fuelwood collection. Mechanized ploughing of dune slopes and sandy plains during the last three decades has increased the potentials of wind erosion manifold (Kar 1996).

\subsection{Aeolian record from the southern margin of the Thar}

In the southern margin of the Thar aeolian sand is seen in areas where the present day annual rainfall is up to $1000 \mathrm{~mm}$, and it occurs especially on the pediment plains, upland terraces and coastal plains, spanning the Sabarmati basin in the north and the Mahi basin in the south (Juyal et al 2003). Most sand dunes are poorly organised (3-6 m high), while along the hills obstacle dunes (8-10 $\mathrm{m}$ high) have also been formed. Studies on six dune profiles along a roughly N-S transect at Dharoi (2 sections), Akhaj, Dabka and Tajpura (2 sections) revealed that all the dunes had multiple phases of accretion, with ages ranging from $26 \mathrm{ka}$ to $6 \mathrm{ka}$ in the upper $6 \mathrm{~m}$ (i.e., after the marine isotope stage 3 ). Some of the ages correspond to the LGM, and could have formed despite a weak SW monsoon, due to local factors like adequate sediment supply from a large alluvial plain in the proximity of a falling sea level and a favourable sea breeze. Although older records could not be reached due to logistic problems of digging deeper, the exposed deposits also documented stability in aggradation process and human occupancy (e.g., microlith culture) during 11-8 ka when the SW monsoon was more vigorous in the region. No later aeolian aggradation was noticed in the Mahi basin sites (Tajpura, Dabka), but the sites in Sabarmati basin (Akhaj, Dharoi) experienced aeolian aggradation till $5 \mathrm{ka}$ (table 3 ). This suggests that with the passage of time the duneforming environment gradually shrank northward and that the southern margin remained relatively free of aeolian deposition thereafter (Juyal et al 2003).

\section{Conclusions}

Our studies in the Thar desert and its wetter eastern fringe provide a basis for understanding the late Quaternary aeolian dynamism in the region and the nature of its relationship with climate. The following broad conclusions could be drawn from the studies:

- The Quaternary aeolian activities in the region are more than $150 \mathrm{ka}$ old, and occur in a cyclic fashion. Further probing with better analytical tools may provide records that are still older, going back to the beginning of the Pleistocene.

- This negates the earlier concepts of Thar being of anthropogenic origin.

- Major phases of pre-LGM aeolian accumulation during the late Pleistocene were between 100 and $115 \mathrm{ka}, \sim 75 \mathrm{ka}, \sim 55 \mathrm{ka}$ and between 30 and $25 \mathrm{ka}$.

- The LGM was a period of high aridity, when the desert could have extended far beyond its present boundary. However, the wind strength during the period was, perhaps, not sufficient to effect large-scale sand mobility and accumulation. Possibly all such periods of dry cool climates in the region experienced lesser aeolian activities. The LGM also experienced reduced fluvial activity.

- Maximum sand mobility and accumulation took place when the SW monsoon wind strength was sufficient during the transition period from an arid phase to a wetter phase and vice versa. Thus, the peak of aridity at $\sim 18$ ka was marked by very less aeolian activities, but the transition to the peak of the next wet phase, the Climatic Optimum (7-6 ka), was marked by strong aeolian activities. The aeolian deposition following the LGM started at $\sim 16 \mathrm{ka}$, but the major activities took place roughly between 14 and $10 \mathrm{ka}$, when sand spread to areas far beyond its present eastern limit.

- High and sustained rainfall events during the peak of strong SW monsoon stopped the aeolian activities and led to landscape stability due to a better moisture regime, higher vegetation cover and improved soil forming processes, as was evident during the Holocene Climatic Optimum.

- A northward shift in dune forming climate during the Holocene was also seen. Thus the southern margin of the mega-Thar in Gujarat did not experience any dune building activity after $10 \mathrm{ka}$, the north Gujarat plain experienced dune aggradation activity up to $5 \mathrm{ka}$, while large parts of west Rajasthan, containing the core of the Thar experienced dune activity even after $2 \mathrm{ka}$ (and up to the present in some parts). This aspect, if modelled, will provide important clues to the spatial shifts in the monsoon through time.

- Within the present desert boundary, the major phases of aeolian activities after the Holocene Climatic Optimum were between 5 and $3.5 \mathrm{ka}$, and 2 and $0.8 \mathrm{ka}$ ( $0.6 \mathrm{ka}$ in the western part). The Harappan and pre-Harappan civilizations in the northern part of the desert flourished during a waning phase of the SW monsoon, when rainfall events were more aberrant, and aeolian activities high. 
- The areas to the east and south of the present desert boundary did not experience large-scale sand mobility and aeolian bedform formation after the Climatic Optimum. In most locations the activities might have stopped by the beginning of the Holocene. Younger aeolian records, if any, have largely been washed out by subsequent higher rainfall.

- Within the desert the rates of present-day sand mobility are found to be higher than the centuryscale rates of sand mobility during the late Quaternary period.

The above is only a first-level understanding of the climate-driven aeolian episodes within the Thar desert. Many research gaps are yet to be filled. For example, further research is necessary to understand how the different aeolian landscape elements responded to the climate-driven processes in the past, especially during the transitional phases. Much of this understanding needs to be based on a proper knowledge of the present-day landscape response mechanism under identical situa- tions. The response time of the aeolian processes to climate change also needs to be researched. A finer resolution aeolian event history is to be constructed through dating and more intensive efforts are needed to understand the impact of climate and humans during the last $3 \mathrm{ka}$, as well as for predicting the possible future response patterns.

\section{Acknowledgements}

This review is an outcome of the DST-sponsored programme on 'Quaternary Stratigraphy and Palaeoenvironmental History of the Thar Desert' (ESS/C-A-03/96). We gratefully thank all our collaborators, A J Kailath, J V Thomas, N Juyal, C Felix, M Chougaonkar, J Andrews, S N Rajaguru and R P Dhir for their invaluable contribution in the field, in the laboratory measurements and in interpretation of the data. All of these inputs provided the basis for this review. AKS thanks Prof. R J Wasson who initiated him into the study of desert land forms.

\section{Appendix I}

Awai Series

Radiocarbon ages on the Thar desert Carbonates

\begin{tabular}{|c|c|c|c|}
\hline Site & Sample No. & Depth (m) & ${ }^{14} \mathrm{C}$ age $\mathrm{aBP}$ \\
\hline PRL-890 & Nachna - 12/3 & $1.25-1.34$ & $19260+940-840$ \\
\hline PRL-891 & Nachna - 12/5 & $1.8-2$ & $>31,000$ \\
\hline PRL-892 & Nachna - 12/7 & $2.3-2.4$ & $>31,000$ \\
\hline PRL-893 & Nachna - 12/9 & $2.5-2.6$ & $>31,000$ \\
\hline PRL-894 & Nachna - $13 / 2$ & 3.0 & $11,420+440-420$ \\
\hline PRL-895 & Nachna - $13 / 3$ & 3.37 & $12,730+480-460$ \\
\hline PRL-896 & Nachna - 13/4 & 3.7 & $24,450+1800-1500$ \\
\hline PRL-897 & Nachna - 13/5 & 4.3 & $25,430+1900-1500$ \\
\hline PRL-898 & Nachna - 13/6 & 4.6 & $29,010+3200-2300$ \\
\hline PRL-899 & Nachna - 15 & 4.5 & $>31,000$ \\
\hline Site & Sample No. & Depth (m) & ${ }^{14} \mathrm{C}$ age $\mathrm{aBP}$ \\
\hline PRL-654 & $\begin{array}{l}\text { Soil carbonate (fine } \\
\text { from Rly cutting }\end{array}$ & $9-9.2 \mathrm{~m}$ & $24,010+1200-1100$ \\
\hline PRL-911 & $\begin{array}{l}\text { Soil carbonate } 16 \mathrm{R} \text { Tr. } \\
\text { A-10 L-1 }\end{array}$ & $5.5-5.55 \mathrm{~m}$ & $26,210+2200-1700$ \\
\hline PRL-912 & $\begin{array}{l}\text { Soil carbonate nodule } \\
\text { site RCD L1 }\end{array}$ & $0.46-0.66 \mathrm{~m}$ & $19,940+930-830$ \\
\hline PRL-913 & Site RCD & $0.98-1 \mathrm{~m}$ & $15,340+450-430$ \\
\hline
\end{tabular}


Shergarh Tri Jn.

\begin{tabular}{llcc}
\hline \multicolumn{1}{c}{ Site } & Sample No. & Depth $(\mathrm{m})$ & ${ }^{14} \mathrm{C}$ age aBP \\
\hline PRL-574 & Caliche & 0.7 & $22,550+560-520$ \\
\hline PRL-575 & Caliche & $2.5-2.6$ & $31,910+2930-2460$ \\
\hline PRL-576 & Caliche & $2.8-3.0$ & $34,200+2080-1660$ \\
\hline PRL-577 & Caliche & $3.28-3.6$ & $37,380+4840-3030$ \\
\hline
\end{tabular}

Naliaser Lake

\begin{tabular}{llcc}
\hline \multicolumn{1}{c}{ Site } & Sample No. & Depth $(\mathrm{m})$ & ${ }^{14} \mathrm{C}$ age aBP \\
\hline PRL-358 & Caliche Lake basin & $0.05 \mathrm{~m}$ & $12,750+290-280$ \\
\hline PRL-359 & Caliche Lake basin & $0.1 \mathrm{~m}$ & $15,50+370-360$ \\
\hline & & $20,000+920-820$ \\
& & $22,320+700-640$ \\
\hline Site & Sample No. & $14 \mathrm{C}$ age aBP \\
\hline PRL-373 & Gudlai Nadi & Depth $(\mathrm{cm})$ & $12,070+460-440$ \\
\hline PRL-374 & Gudlai Nadi & 50 & $15,400+230-220$ \\
& & 140 & $23,570+1090-960$ \\
\hline PRL-375 & Gudlai Nadi & $18,840+600-560$ \\
\hline PRL-376 & Gudlai Nadi & 320 & $27,220+3280-2340$ \\
\hline PRL-379 & Chirai & 115 & $>40,000$ \\
\hline PRL-378 & Chirai & 130 & $23,000+710-650$ \\
\hline PRL-377 & Chirai & 165 & $22,180+600-610$ \\
\hline
\end{tabular}

\section{Appendix II}

Compilation of luminescence ages

Dharoi I (GLSL ages)

\begin{tabular}{cccccccc}
\hline $\begin{array}{l}\text { Sample } \\
\text { No. }\end{array}$ & $\begin{array}{c}\text { Depth } \\
(\mathrm{Cm})\end{array}$ & $\mathrm{U}(\mathrm{ppm})$ & $\mathrm{Th}(\mathrm{ppm})$ & $\mathrm{K}(\%)$ & $\begin{array}{c}\text { Dose rate } \\
(\mathrm{Gy} / \mathrm{ka})\end{array}$ & $\mathrm{De}(\mathrm{Gy})$ & Age $(\mathrm{ka})$ \\
\hline TR-249 & 20 & $2.04 \pm 0.44$ & $7.03 \pm 1.51$ & $1.28 \pm 0.06$ & $2.2 \pm 0.2$ & $12 \pm 3$ & $6 \pm 1$ \\
\hline TR-250 & 80 & $2.17 \pm 0.41$ & $5.68 \pm 1.43$ & $1.73 \pm 0.08$ & $2.5 \pm 0.2$ & $19 \pm 2$ & $8 \pm 1$ \\
\hline TR-252 & 130 & $0.90 \pm 0.42$ & $5.87 \pm 1.46$ & $1.19 \pm 0.06$ & $1.8 \pm 0.2$ & $18 \pm 5$ & $10 \pm 3$ \\
\hline TR-254 & 230 & $0.99 \pm 0.39$ & $6.26 \pm 1.33$ & $1.21 \pm 0.06$ & $1.8 \pm 0.2$ & $20 \pm 6$ & $11 \pm 3$ \\
\hline TR-255 & 350 & $1.61 \pm 0.29$ & $2.83 \pm 0.01$ & $1.27 \pm 0.06$ & $1.8 \pm 0.1$ & $22 \pm 5$ & $12 \pm 3$ \\
\hline TR-253 & 500 & $1.31 \pm 0.02$ & $3.47 \pm 0.78$ & $1.08 \pm 0.05$ & $1.6 \pm 0.1$ & $34 \pm 2$ & $21 \pm 2$ \\
\hline TR-256 & 620 & $1.44 \pm 0.45$ & $8.93 \pm 1.57$ & $1.38 \pm 0.07$ & $2.3 \pm 0.2$ & $42 \pm 10$ & $19 \pm 5$ \\
\hline
\end{tabular}


Dharoi II (GLSL ages)

\begin{tabular}{lccccccc}
\hline $\begin{array}{l}\text { Sample } \\
\text { No. }\end{array}$ & $\begin{array}{c}\text { Depth } \\
(\mathrm{Cm})\end{array}$ & $\mathrm{U}(\mathrm{ppm})$ & $\mathrm{Th}(\mathrm{ppm})$ & $\mathrm{K}(\%)$ & $\begin{array}{c}\text { Dose rate } \\
(\mathrm{Gy} / \mathrm{ka})\end{array}$ & $\mathrm{De}(\mathrm{Gy})$ & Age $(\mathrm{ka})$ \\
\hline TR-257 & 400 & $1.05 \pm 0.26$ & $3.70 \pm 0.90$ & $1.02 \pm 0.05$ & $1.5 \pm 0.4$ & $32 \pm 2$ & $21 \pm 2$ \\
\hline TR-258 & 450 & $0.91 \pm 0.25$ & $3.66 \pm 0.90$ & $0.80 \pm 0.04$ & $1.3 \pm 0.1$ & $21 \pm 4$ & $16 \pm 3$ \\
\hline TR-259 & 600 & $1.04 \pm 0.22$ & $3.89 \pm 0.78$ & $0.98 \pm 0.05$ & $1.5 \pm 0.1$ & $37 \pm 8$ & $25 \pm 6$ \\
\hline
\end{tabular}

Akhaj (GLSL ages)

\begin{tabular}{lccccccc}
\hline $\begin{array}{l}\text { Sample } \\
\text { No. }\end{array}$ & $\begin{array}{c}\text { Depth } \\
(\mathrm{Cm})\end{array}$ & $\mathrm{U}(\mathrm{ppm})$ & $\mathrm{Th}(\mathrm{ppm})$ & $\mathrm{K}(\%)$ & $\begin{array}{c}\text { Dose rate } \\
\text { (Gy/ka) }\end{array}$ & De(Gy) & Age $(\mathrm{ka})$ \\
\hline TR-243 & 50 & $1.12 \pm 0.45$ & $6.33 \pm 1.52$ & $0.4 \pm 0.02$ & $1.2 \pm 0.2$ & $8 \pm 0.2$ & $7 \pm 1$ \\
\hline TR-244 & 145 & $1.41 \pm 0.42$ & $4.70 \pm 1.44$ & $1.18 \pm 0.05$ & $1.8 \pm 0.2$ & $16 \pm 2$ & $9 \pm 1$ \\
\hline TR-246 & 180 & $1.09 \pm 0.30$ & $3.36 \pm 1.00$ & $0.85 \pm 0.04$ & $1.3 \pm 0.1$ & $22 \pm 5$ & $11 \pm 3$ \\
\hline TR-248 & 300 & $0.74 \pm 0.31$ & $5.57 \pm 1.10$ & $0.97 \pm 0.04$ & $1.5 \pm 0.1$ & $39 \pm 5$ & $26 \pm 4$ \\
\hline
\end{tabular}

Tajpura I (GLSL ages)

\begin{tabular}{lccccccc}
\hline $\begin{array}{l}\text { Sample } \\
\text { No. }\end{array}$ & $\begin{array}{c}\text { Depth } \\
(\mathrm{Cm})\end{array}$ & $\mathrm{U}(\mathrm{ppm})$ & $\mathrm{Th}(\mathrm{ppm})$ & $\mathrm{K}(\%)$ & $\begin{array}{c}\text { Dose rate } \\
(\mathrm{Gy} / \mathrm{ka})\end{array}$ & $\mathrm{De}(\mathrm{Gy})$ & Age $(\mathrm{ka})$ \\
\hline TR-233 & 70 & $1.25 \pm 0.40$ & $5.63 \pm 1.37$ & $1.60 \pm 0.10$ & $2.2 \pm 0.2$ & $0.4 \pm 0.2$ & 0.20 .01 \\
\hline TR-232 & 85 & $1.01 \pm 0.30$ & $5.57 \pm 1.00$ & $0.75 \pm 0.04$ & $1.4 \pm 0.1$ & $17 \pm 5$ & $12 \pm 4$ \\
\hline TR-229 & 160 & $1.27 \pm 0.20$ & $3.35 \pm 0.73$ & $0.60 \pm 0.03$ & $1.2 \pm 0.1$ & $16 \pm 2$ & $14 \pm 2$ \\
\hline TR-225 & 370 & $0.93 \pm 0.02$ & $3.90 \pm 0.74$ & $1.27 \pm 0.06$ & $1.7 \pm 0.1$ & $30 \pm 4$ & $17 \pm 3$ \\
\hline
\end{tabular}

Tajpura II (GLSL ages)

\begin{tabular}{lccccccc}
\hline $\begin{array}{l}\text { Sample } \\
\text { No. }\end{array}$ & $\begin{array}{c}\text { Depth } \\
(\mathrm{Cm})\end{array}$ & $\mathrm{U}(\mathrm{ppm})$ & $\mathrm{Th}(\mathrm{ppm})$ & $\mathrm{K}(\%)$ & $\begin{array}{c}\text { Dose rate } \\
(\mathrm{Gy} / \mathrm{ka})\end{array}$ & $\mathrm{De}(\mathrm{Gy})$ & Age $(\mathrm{ka})$ \\
\hline TR-260a & 50 & $1.58 \pm 0.33$ & $3.53 \pm 1.12$ & $1.34 \pm 0.07$ & $2.0 \pm 0.2$ & $37 \pm 7$ & $20 \pm 4$ \\
\hline TR-260b & 330 & $1.16 \pm 0.41$ & $6.31 \pm 1.41$ & $1.08 \pm 0.05$ & $1.7 \pm 0.2$ & $32 \pm 1$ & $18 \pm 2$ \\
\hline TR-261 & 390 & $0.95 \pm 0.26$ & $5.25 \pm 0.91$ & $1.04 \pm 0.05$ & $1.6 \pm 0.1$ & $75 \pm 19$ & $46 \pm 12$ \\
\hline TR-262 & 390 & $0.85 \pm 0.21$ & $3.91 \pm 0.76$ & $1.08 \pm 0.05$ & $1.5 \pm 0.1$ & $34 \pm 6$ & $22 \pm 4$ \\
\hline TR-263 & 600 & $0.62 \pm 0.25$ & $6.02 \pm 0.88$ & $1.18 \pm 0.06$ & $1.7 \pm 0.1$ & $39 \pm 3$ & $23 \pm 3$ \\
\hline
\end{tabular}

\section{Dabka}

\begin{tabular}{lccccccc}
\hline $\begin{array}{l}\text { Sample } \\
\text { No. }\end{array}$ & $\begin{array}{c}\text { Depth } \\
(\mathrm{Cm})\end{array}$ & $\mathrm{U}(\mathrm{ppm})$ & $\mathrm{Th}(\mathrm{ppm})$ & $\mathrm{K}(\%)$ & $\begin{array}{c}\text { Dose rate } \\
(\mathrm{Gy} / \mathrm{ka})\end{array}$ & De $(\mathrm{Gy})$ & Age $(\mathrm{ka})$ \\
\hline TR-242 & 60 & $1.51 \pm 0.47$ & $7.97 \pm 1.61$ & $1.17 \pm 0.06$ & $2.0 \pm 0.2$ & $38 \pm 9$ & $19 \pm 5$ \\
\hline TR-241 & 150 & $2.14 \pm 0.50$ & $6.27 \pm 1.69$ & $1.14 \pm 0.06$ & $2.0 \pm 0.2$ & $44 \pm 6$ & $22 \pm 4$ \\
\hline
\end{tabular}

Thirana (TL dates)

\begin{tabular}{lccccccr}
\hline Sample & Depth $(\mathrm{cm})$ & $\mathrm{U}(\mathrm{ppm})$ & $\mathrm{Th}(\mathrm{ppm})$ & $\mathrm{K}(\%)$ & $\begin{array}{c}\text { Dose rate } \\
(\mathrm{Gy} / \mathrm{ka})\end{array}$ & $D_{e}(\mathrm{~Gy})$ & Age $(\mathrm{ka})$ \\
\hline TR-63 & 60 & $1.69 \pm 0.73$ & $11.24 \pm 2.51$ & $2.04 \pm 0.10$ & $3.23 \pm 0.29$ & $0.65 \pm 0.10$ & $0.2 \pm 0.04$ \\
\hline TR-64 & 90 & $2.20 \pm 0.69$ & $8.67 \pm 2.37$ & $1.70 \pm 0.08$ & $2.84 \pm 0.27$ & $1.48 \pm 0.03$ & $0.5 \pm 0.05$ \\
\hline TR-65 & 120 & $1.87 \pm 0.91$ & $10.35 \pm 3.14$ & $1.68 \pm 0.10$ & $2.94 \pm 0.34$ & $10.69 \pm 0.83$ & $3.64 \pm 0.51$ \\
\hline
\end{tabular}


Thirana (TL dates) (Continued)

\begin{tabular}{lccccccc}
\hline Sample & Depth $(\mathrm{cm})$ & $\mathrm{U}(\mathrm{ppm})$ & Th $(\mathrm{ppm})$ & $\mathrm{K}(\%)$ & $\begin{array}{c}\text { Dose rate } \\
(\mathrm{Gy} / \mathrm{ka})\end{array}$ & $D_{e}(\mathrm{~Gy})$ & Age $(\mathrm{ka})$ \\
\hline TR-66 & 150 & $1.91 \pm 0.65$ & $7.68 \pm 2.21$ & $1.59 \pm 0.10$ & $2.67 \pm 0.26$ & $12.04 \pm 1.91$ & $4.5 \pm 0.84$ \\
\hline TR-67 & 200 & $2.46 \pm 0.63$ & $5.99 \pm 2.17$ & $1.35 \pm 0.07$ & $2.45 \pm 0.24$ & $12.41 \pm 1.11$ & $5.08 \pm 0.68$ \\
\hline TR-68 & 80 & $2.04 \pm 0.49$ & $8.98 \pm 1.66$ & $1.70 \pm 0.09$ & $2.83 \pm 0.21$ & $1.16 \pm 0.5$ & $0.4 \pm 0.18$ \\
\hline TR-69 & 100 & $2.25 \pm 0.70$ & $7.36 \pm 2.38$ & $1.67 \pm 0.08$ & $2.80 \pm 0.27$ & $1.26 \pm 1.42$ & $0.45 \pm 0.51$ \\
\hline TR-70 & 190 & $2.21 \pm 0.65$ & $7.99 \pm 2.22$ & $1.50 \pm 0.10$ & $2.68 \pm 0.26$ & $2.22 \pm 0.86$ & $0.83 \pm 0.33$ \\
\hline TR-71 & 250 & $2.86 \pm 0.79$ & $8.57 \pm 2.70$ & $1.75 \pm 0.09$ & $3.03 \pm 0.30$ & $15.99 \pm 1.39$ & $5.35 \pm 0.69$ \\
\hline TR-72 & 290 & $2.58 \pm 0.66$ & $7.31 \pm 2.27$ & $1.50 \pm 0.10$ & $2.71 \pm 0.26$ & $20.45 \pm 0.46$ & $7.54 \pm 0.75$ \\
\hline TR-73 & 325 & $2.66 \pm 0.75$ & $7.45 \pm 2.55$ & $1.34 \pm 0.07$ & $2.59 \pm 0.28$ & $19.68 \pm 1.08$ & $7.60 \pm 0.92$ \\
\hline TR-75 & 370 & $2.42 \pm 0.74$ & $7.47 \pm 0.74$ & $1.28 \pm 0.06$ & $2.48 \pm 0.28$ & $31.20 \pm 1.97$ & $12.59 \pm 1.61$ \\
\hline TR-76 & 390 & $1.95 \pm 0.74$ & $9.22 \pm 2.52$ & $1.54 \pm 0.08$ & $2.74 \pm 0.28$ & $26.98 \pm 1.79$ & $9.83 \pm 1.20$ \\
\hline TR-77 & 100 & $1.36 \pm 0.71$ & $9.44 \pm 2.45$ & $1.68 \pm 0.09$ & $2.76 \pm 0.27$ & $1.29 \pm 0.46$ & $0.47 \pm 0.17$ \\
\hline TR-78 & 120 & $2.70 \pm 0.69$ & $6.74 \pm 2.30$ & $1.72 \pm 0.09$ & $2.91 \pm 0.27$ & $1.02 \pm 1.72$ & $0.35 \pm 0.59$ \\
\hline TR-79 & 140 & $2.31 \pm 0.74$ & $8.54 \pm 2.52$ & $1.45 \pm 0.08$ & $2.69 \pm 0.28$ & $14.26 \pm 1.17$ & $5.30 \pm 0.70$ \\
\hline
\end{tabular}

Thirana (GLSL dates)

\begin{tabular}{lcccccc}
\hline Sample & $\mathrm{U}(\mathrm{ppm})$ & $\mathrm{Th}(\mathrm{ppm})$ & $\mathrm{K}(\%)$ & $D_{e}(\mathrm{~Gy})$ & $\begin{array}{c}\text { Dose rate } \\
(\mathrm{Gy} / \mathrm{ka})\end{array}$ & Age $(\mathrm{ka})$ \\
\hline TR-65 & $1.87 \pm 0.91$ & $10.35 \pm 3.14$ & 1.68 & $8.32 \pm 3.33$ & $2.9 \pm 0.34$ & $2.8 \pm 1.2$ \\
\hline TR-66 & $1.91 \pm 0.65$ & $7.68 \pm 2.21$ & 1.59 & $12.20 \pm 4.93$ & $2.67 \pm 0.26$ & $4.6 \pm 1.9$ \\
\hline TR-67 & $2.46 \pm 0.65$ & $5.99 \pm 2.17$ & 1.5 & $17.00 \pm 6.01$ & $2.59 \pm 0.24$ & $6.6 \pm 2.4$ \\
\hline TR-69 & $2.21 \pm 0.65$ & $7.36 \pm 2.38$ & 1.5 & $0.22 \pm 0.00$ & $2.64 \pm 0.27$ & $0.1 \pm 0.01$ \\
\hline TR-70 & $2.21 \pm 0.65$ & $7.99 \pm 2.22$ & 1.5 & $1.08 \pm 0.68$ & $2.68 \pm 0.26$ & $0.4 \pm 0.25$ \\
\hline TR-72 & $2.58 \pm 0.66$ & $7.31 \pm 2.27$ & 1.49 & $25.81 \pm 0.26$ & $9.5 \pm 3.4$ & $7.5 \pm .08$ \\
\hline TR-73 & $2.66 \pm 0.75$ & $7.45 \pm 2.55$ & 1.5 & $9.39 \pm 6.01$ & $2.74 \pm 0.29$ & $3.4 \pm 2.2$ \\
\hline TR-75 & $2.42 \pm 0.74$ & $7.47 \pm 2.54$ & 1.5 & $2.69 \pm 0.29$ & $8.5 \pm 2.2$ & $11.6 \pm 1.4$ \\
\hline TR-76 & $1.95 \pm 0.74$ & $9.22 \pm 2.52$ & 1.5 & $19.37 \pm 7.88$ & $2.71 \pm 0.29$ & $7.2 \pm 3.0$ \\
\hline TR-77 & $1.36 \pm 0.71$ & $9.44 \pm 2.45$ & 1.5 & $0.86 \pm 0.18$ & $2.59 \pm 0.28$ & $0.3 \pm 0.1$ \\
\hline TR-78 & $2.70 \pm 0.69$ & $6.74 \pm 2.30$ & 1.5 & $1.36 \pm 0.09$ & $2.70 \pm 0.27$ & $0.5 \pm 0.1$ \\
\hline TR-79 & $2.31 \pm 0.74$ & $8.54 \pm 2.52$ & 1.5 & $13.98 \pm 2.46$ & $2.74 \pm 0.29$ & $5.1 \pm 1.0$ \\
\hline
\end{tabular}

\section{Sahjasar (GLSL dates)}

\begin{tabular}{lcccccc}
\hline Sample & $\mathrm{U}(\mathrm{ppm})$ & $\mathrm{Th}(\mathrm{ppm})$ & $\mathrm{K}(\%)$ & $D_{e}(\mathrm{~Gy})$ & $\begin{array}{c}\text { Dose rate } \\
\text { (Gy/ka) }\end{array}$ & Age (a) \\
\hline TR-80 & $2.59 \pm 0.74$ & $7.07 \pm 2.53$ & 1.5 & $0.17 \pm 0.02$ & $2.70 \pm 0.39$ & $63 \pm 11$ \\
\hline TR-81 & $2.17 \pm 0.75$ & $8.84 \pm 2.59$ & 1.5 & $0.54 \pm 0.16$ & $2.73 \pm 0.40$ & $108 \pm 65$ \\
\hline TR-82 & $2.52 \pm 0.59$ & $5.36 \pm 2.03$ & 1.5 & $0.34 \pm 0.05$ & $2.56 \pm 0.36$ & $133 \pm 27$ \\
\hline TR-83 & $1.82 \pm 0.69$ & $9.06 \pm 2.36$ & 1.5 & $0.40 \pm 0.01$ & $2.66 \pm 0.38$ & $150 \pm 21$ \\
\hline TR-84 & $1.64 \pm 0.37$ & $4.30 \pm 0.37$ & 1.5 & $0.43 \pm 0.06$ & $2.27 \pm 0.32$ & $189 \pm 37$ \\
\hline
\end{tabular}


Sahjasar (GLSL dates) (Continued)

\begin{tabular}{|c|c|c|c|c|c|c|}
\hline Sample & $\mathrm{U}(\mathrm{ppm})$ & Th (ppm) & $\mathrm{K}(\%)$ & $D_{e}(\mathrm{~Gy})$ & $\begin{array}{c}\text { Dose rate } \\
(\mathrm{Gy} / \mathrm{ka})\end{array}$ & Age (a) \\
\hline TR-85 & $1.49 \pm 0.40$ & $5.22 \pm 1.37$ & 1.5 & $3.2 \pm 0.46$ & $2.30 \pm 0.33$ & $1390 \pm 300$ \\
\hline TR-86 & $1.86 \pm 0.60$ & $6.92 \pm 2.07$ & 1.81 & $60.15 \pm 12.84$ & $2.81 \pm 0.30$ & $2140 \pm 507$ \\
\hline TR-87 & $1.30 \pm 0.64$ & $8.35 \pm 2.19$ & 1.36 & $46.72 \pm 4.4$ & $2.36 \pm 0.30$ & $19800 \pm 3100$ \\
\hline
\end{tabular}

Sirohi (Malpura) (IRSL dates)

\begin{tabular}{lcccccc}
\hline Sample & $\mathrm{U}(\mu \mathrm{g} / \mathrm{gm})$ & $\mathrm{Th}(\mu \mathrm{g} / \mathrm{gm})$ & $\mathrm{K}(\%)$ & Dose rate $(\mathrm{Gy} / \mathrm{ka})$ & $D_{e}(\mathrm{~Gy})$ & Age $(\mathrm{ka})$ \\
\hline TR-51 & $1.15 \pm 0.37$ & $6.97 \pm 1.28$ & 1.08 & $2.39 \pm 0.18$ & $17.21 \pm 1.64$ & $7.19 \pm 0.87$ \\
\hline TR-52 & $1.96 \pm 0.55$ & $6.33 \pm 1.88$ & 1.12 & $2.57 \pm 0.23$ & $12.32 \pm 1.27$ & $18.0 \pm 1.4$ \\
\hline TR-53 & $0.61 \pm 0.35$ & $6.02 \pm 1.23$ & 1.30 & $2.41 \pm 0.18$ & $20.12 \pm 1.1$ & $22.6 \pm 1.4$ \\
\hline TR-54 & $1.05 \pm 0.26$ & $4.13 \pm 0.93$ & 0.95 & $2.04 \pm 0.16$ & $20.88 \pm 1.52$ & $10.9 \pm 1.08$ \\
\hline TR-55 & $1.54 \pm 0.26$ & $2.97 \pm 0.89$ & 0.59 & $1.73 \pm 0.15$ & $64.98 \pm 3.15$ & $37.6 \pm 3.8$ \\
\hline TR-56 & $0.95 \pm 0.20$ & $3.05 \pm 0.74$ & 0.57 & $1.58 \pm 0.15$ & $91.06 \pm 19.07$ & $57.7 \pm 13.21$ \\
\hline TR-57 & $1.05 \pm 0.16$ & $2.27 \pm 0.58$ & 0.59 & $1.56 \pm 0.14$ & $101.94 \pm 15.0$ & $65.2 \pm 11.19$ \\
\hline TR-58 & $1.24 \pm 0.16$ & $1.62 \pm 0.56$ & 0.56 & $1.53 \pm 0.14$ & $114.14 \pm 0.96$ & $74.5 \pm 6.74$ \\
\hline
\end{tabular}

Sirohi (Malpura) (IRSL dates - Ultimate partial bleach method)

\begin{tabular}{lcccccc}
\hline Sample & $\mathrm{U}(\mu \mathrm{g} / \mathrm{gm})$ & $\mathrm{Th}(\mu \mathrm{g} / \mathrm{gm})$ & $\mathrm{K}(\%)$ & Dose rate $(\mathrm{Gy} / \mathrm{ka})$ & $D_{e}(\mathrm{~Gy})$ & Age $(\mathrm{ka})$ \\
\hline TR-51 & $1.15 \pm 0.37$ & $6.97 \pm 1.28$ & 1.08 & $2.39 \pm 0.18$ & $14.31 \pm 1.36$ & $6.0 \pm 0.73$ \\
\hline TR-54 & $1.05 \pm 0.26$ & $4.13 \pm 0.93$ & 0.95 & $2.04 \pm 0.16$ & $18.79 \pm 1.37$ & $9.2 \pm 0.97$ \\
\hline TR-55 & $1.54 \pm 0.26$ & $2.97 \pm 0.89$ & 0.59 & $1.73 \pm 0.15$ & $53.39 \pm 2.59$ & $31 \pm 3$ \\
\hline TR-56 & $0.95 \pm 0.20$ & $3.05 \pm 0.74$ & 0.57 & $1.58 \pm 0.15$ & $81.33 \pm 12.84$ & $39 \pm 9$ \\
\hline TR-57 & $1.05 \pm 0.16$ & $2.27 \pm 0.58$ & 0.59 & $1.56 \pm 0.14$ & $77.55 \pm 11.41$ & $50 \pm 8.5$ \\
\hline
\end{tabular}

Chamu 2 (IRSL ages)

\begin{tabular}{lccccccc}
\hline Sample & $\begin{array}{c}\text { Depth } \\
(\mathrm{cm})\end{array}$ & $\mathrm{U}(\mathrm{ppm})$ & $\mathrm{Th}(\mathrm{ppm})$ & $\mathrm{K}(\%)$ & $\begin{array}{c}\text { Dose rate } \\
(\mathrm{Gy} / \mathrm{ka})\end{array}$ & $D_{e}(\mathrm{~Gy})$ & Age $(\mathrm{ka})$ \\
\hline TR-CH1 & 50 & $2.15 \pm 0.93$ & $12.20 \pm 3.18$ & $1.69 \pm 0.10$ & $3.59 \pm 0.34$ & $0.20 \pm 0.00$ & $0.06 \pm 0.01$ \\
\hline TR-6 & 650 & $1.51 \pm 0.43$ & $6.38 \pm 1.49$ & $1.63 \pm 0.10$ & $2.96 \pm 0.20$ & $40.79 \pm 8.0$ & $13.7 \pm 2.9$ \\
\hline TR-7 & 690 & $1.49 \pm 0.37$ & $8.39 \pm 1.29$ & $1.38 \pm 0.10$ & $2.86 \pm 0.18$ & $50.16 \pm 4.4$ & $17.5 \pm 1.9$ \\
\hline TR-8 & 750 & $0.96 \pm 0.65$ & $9.59 \pm 2.23$ & $1.52 \pm 0.10$ & $2.96 \pm 0.26$ & $70.89 \pm 2.8$ & $26.98 \pm 2.5$ \\
\hline TR-9 & 810 & $2.50 \pm 0.51$ & $6.96 \pm 1.75$ & $1.43 \pm 0.10$ & $3.04 \pm 0.22$ & $83.46 \pm 5.8$ & $27.5 \pm 2.7$ \\
\hline TR-10 & 890 & $1.94 \pm 0.50$ & $4.75 \pm 1.71$ & $1.67 \pm 0.10$ & $2.98 \pm 0.22$ & $173.90 \pm 11.2$ & $58.3 \pm 5.6$ \\
\hline TR-12 & 1010 & $1.24 \pm 0.68$ & $9.50 \pm 2.34$ & $1.38 \pm 0.10$ & $2.89 \pm 0.27$ & $290.70 \pm 13.4$ & $100.8 \pm 10.4$ \\
\hline TR-15 & 1210 & $1.66 \pm 0.41$ & $5.90 \pm 1.39$ & $1.60 \pm 0.10$ & $2.93 \pm 0.19$ & $315.95 \pm 10.1$ & $107.7 \pm 7.8$ \\
\hline TR-16 & 1270 & $1.24 \pm 0.33$ & $5.70 \pm 1.18$ & $1.94 \pm 0.10$ & $3.15 \pm 0.18$ & $287.05 \pm 2.5$ & $91.2 \pm 8.8$ \\
\hline TR-17 & 1350 & $1.70 \pm 0.82$ & $11.38 \pm 2.81$ & $1.56 \pm 0.10$ & $3.30 \pm 0.31$ & $243.00 \pm 11.6$ & $73.7 \pm 7.8$ \\
\hline TR-19 & 1360 & $2.09 \pm 0.70$ & $9.68 \pm 0.70$ & $1.57 \pm 0.10$ & $3.28 \pm 0.27$ & $265.60 \pm 26.7$ & $81.07 \pm 10.6$ \\
\hline TR-151 & 1480 & $1.96 \pm 0.53$ & $5.88 \pm 1.81$ & $1.64 \pm 0.10$ & $3.04 \pm 0.22$ & $306.18 \pm 101.8$ & $100.73 \pm 34.3$ \\
\hline
\end{tabular}


Chamu 2 (IRSL ages) (Continued)

\begin{tabular}{lccccccc}
\hline Sample & $\begin{array}{c}\text { Depth } \\
(\mathrm{cm})\end{array}$ & $\mathrm{U}(\mathrm{ppm})$ & $\mathrm{Th}(\mathrm{ppm})$ & $\mathrm{K}(\%)$ & $\begin{array}{c}\text { Dose rate } \\
(\mathrm{Gy} / \mathrm{ka})\end{array}$ & $D_{e}(\mathrm{~Gy})$ & Age $(\mathrm{ka})$ \\
\hline TR-CH21 & 1590 & $3.32 \pm 1.11$ & $8.92 \pm 3.76$ & $0.99 \pm 0.10$ & $2.95 \pm 0.40$ & $295.19 \pm 51.5$ & $100.1 \pm 22.04$ \\
\hline TR-CH22 & 1610 & $1.69 \pm 0.66$ & $7.95 \pm 2.24$ & $1.21 \pm 0.10$ & $2.71 \pm 0.26$ & $223.14 \pm 20.96$ & $82.21 \pm 10.99$ \\
\hline TR-152 & 1800 & $0.12 \pm 0.13$ & $2.52 \pm 0.47$ & $1.59 \pm 0.10$ & $2.33 \pm 0.14$ & $351.81 \pm 67.6$ & $151.29 \pm 30.4$ \\
\hline
\end{tabular}

Jamsar (GLSL ages)

\begin{tabular}{lccccccc}
\hline Sample & $\begin{array}{c}\text { Depth } \\
(\mathrm{cm})\end{array}$ & $\mathrm{U}(\mathrm{ppm})$ & $\mathrm{Th}(\mathrm{ppm})$ & $\mathrm{K}(\%)$ & $\begin{array}{c}\text { Dose rate } \\
\left.(\mathrm{Gy} \mathrm{ka})^{-1}\right)\end{array}$ & $D_{e}(\mathrm{~Gy})$ & Age $(\mathrm{ka})$ \\
\hline TR89 & 80 & $2.40 \pm 0.77$ & $10.50 \pm 2.60$ & $1.68 \pm 0.09$ & $3.00 \pm 0.28$ & $0.88 \pm 0.05$ & $0.3 \pm 0.03$ \\
\hline TR90 & 130 & $2.00 \pm 0.94$ & $15.53 \pm 3.22$ & $1.42 \pm 0.07$ & $3.00 \pm 0.33$ & $5.7 \pm 0.6$ & $1.9 \pm 0.3$ \\
\hline TR92 & 200 & $2.28 \pm 0.97$ & $11.32 \pm 2.62$ & $1.65 \pm 0.08$ & $3.00 \pm 0.31$ & $14.1 \pm 2.4$ & $4.7 \pm 0.9$ \\
\hline TR93 & 220 & $2.34 \pm 0.76$ & $10.74 \pm 2.62$ & $1.30 \pm 0.06$ & $2.64 \pm 0.27$ & $13.6 \pm 4.7$ & $5.2 \pm 1.8$ \\
\hline TR98 & 365 & $2.25 \pm 0.81$ & $11.20 \pm 2.79$ & $1.50 \pm 0.08$ & $2.84 \pm 0.29$ & $14.4 \pm 3.9$ & $5.1 \pm 1.4$ \\
\hline TR99 & 390 & $21.25 \pm 0.53$ & $7.82 \pm 1.83$ & $1.36 \pm 0.07$ & $2.47 \pm 0.20$ & $13.2 \pm 1.4$ & $5.3 \pm 0.7$ \\
\hline TR62 & 140 & $3.97 \pm 1.32$ & $11.29 \pm 4.48$ & $1.31 \pm 0.06$ & $3.05 \pm 0.44$ & $16.5 \pm 3.1$ & $5.4 \pm 1.3$ \\
\hline
\end{tabular}

\section{Amarsar - I (TL ages)}

\begin{tabular}{lcccccc}
\hline $\begin{array}{l}\text { Sample Code, } \\
\text { Depth }(\mathrm{m})\end{array}$ & $\mathrm{Th}(\mathrm{ppm})$ & $\mathrm{U}(\mathrm{ppm})$ & $\mathrm{K}(\%)$ & $\begin{array}{l}\text { Dose rate } \\
(\mathrm{Gy} / \mathrm{ka})\end{array}$ & $D_{e}(\mathrm{~Gy})$ & Age $(\mathrm{ka})$ \\
\hline $\operatorname{Tr} 27(0.50)$ & $11.31 \pm 2.08$ & $2.57 \pm 0.61$ & $1.14 \pm 0.15$ & $2.74 \pm 0.46$ & $43.1 \pm 2.7$ & $16 \pm 2.4$ \\
\hline $\operatorname{Tr} 28(1.09)$ & $13.67 \pm 2.22$ & $3.14 \pm 0.65$ & $1.04 \pm 0.01$ & $2.98 \pm 0.36$ & $47.9 \pm 5.3$ & $16 \pm 2.2$ \\
\hline $\operatorname{Tr} 32(3.53)$ & $7.04 \pm 1.92$ & $3.67 \pm 0.56$ & $1.09 \pm 0.05$ & $2.63 \pm 0.34$ & $88.9 \pm 9.4$ & $34 \pm 4.7$ \\
\hline $\operatorname{Tr} 33(4.42)$ & $14.36 \pm 1.81$ & $1.93 \pm 0.52$ & $1.01 \pm 0.08$ & $2.69 \pm 0.30$ & $158.0 \pm 15.0$ & $59 \pm 7.1$ \\
\hline $\operatorname{Tr} 34(5.02)$ & $14.45 \pm 1.91$ & $1.76 \pm 0.56$ & $0.76 \pm 0.03$ & $2.45 \pm 0.33$ & $159.5 \pm 28.5$ & $66 \pm 12.1$ \\
\hline $\operatorname{Tr} 36(6.42)$ & $12.99 \pm 1.55$ & $0.97 \pm 0.45$ & $0.97 \pm 0.04$ & $2.30 \pm 0.28$ & $171.1 \pm 26.6$ & $75 \pm 12.2$ \\
\hline Amarsar $-\mathbf{I I}(\mathbf{T L}$ ages $)$ & $11.07 \pm 1.73$ & $2.44 \pm 0.51$ & $0.95 \pm 0.03$ & $2.52 \pm 0.29$ & $26.5 \pm 3.6$ & $11 \pm 1.5$ \\
\hline $\operatorname{Tr} 37(0.70)$ & $24.11 \pm 2.18$ & $1.79 \pm 0.64$ & $0.93 \pm 0.01$ & $3.38 \pm 0.35$ & $102.6 \pm 6.0$ & $31 \pm 3.0$ \\
\hline $\operatorname{Tr} 38(1.70)$ & $17.87 \pm 1.88$ & $1.15 \pm 0.55$ & $0.98 \pm 0.02$ & $2.75 \pm 0.31$ & $86.6 \pm 7.7$ & $32 \pm 3.8$ \\
\hline $\operatorname{Tr} 39(2.20)$ & $11.4 \pm 1.94$ & $2.86 \pm 0.57$ & $1.01 \pm 0.03$ & $2.7 \pm 0.32$ & $93.2 \pm 10.8$ & $35 \pm 4.7$ \\
\hline $\operatorname{Tr} 40(3.20)$ & & & & & & \\
\hline
\end{tabular}

\section{Ghughalia (IRSL ages)}

\begin{tabular}{lcccccc}
\hline Sample & $\mathrm{U}(\mu \mathrm{g} / \mathrm{gm})$ & $\mu \mathrm{g} / \mathrm{g}$ & $\mathrm{K}(\%)$ & $\begin{array}{c}\text { Dose rate } \\
(\mathrm{Gy} / \mathrm{ka})\end{array}$ & $D_{e}(\mathrm{~Gy})$ & Age $(\mathrm{a})$ \\
\hline TR-42 & $0.95 \pm 0.57$ & $10.26 \pm 1.95$ & 1.46 & $2.95 \pm 0.24$ & $2.11 \pm 0.09$ & $715 \pm 64$ \\
\hline TR-43 & $2.45 \pm 0.45$ & $6.53 \pm 1.52$ & 1.53 & $3.09 \pm 0.23$ & $8.99 \pm 0.14$ & $2906 \pm 195$ \\
\hline TR-45 & $2.52 \pm 0.40$ & $6.70 \pm 1.38$ & 1.47 & $3.07 \pm 0.19$ & $16.6 \pm 01$ & $5400 \pm 300$ \\
\hline
\end{tabular}


Khara and Bharmasar (IRSL ages)

\begin{tabular}{lcccccc}
\hline Sample & $\mathrm{U}(\mathrm{ppm})$ & $\mathrm{Th}(\mathrm{ppm})$ & $\mathrm{K}^{*}(\%)$ & $\begin{array}{c}\text { Dose rate } \\
(\mathrm{Gy} / \mathrm{ka})\end{array}$ & $D_{e}(\mathrm{~Gy})$ & Age $(\mathrm{a})$ \\
\hline Khara & $1.27 \pm 0.74$ & $10.39 \pm 2.53$ & 1.55 & $2.85 \pm 0.19$ & $1.66 \pm 0.06$ & $580 \pm 44$ \\
\hline TR-20 & $1.9 \pm 0.62$ & $7.53 \pm 2.13$ & 1.49 & $2.73 \pm 0.18$ & $5.36 \pm 0.28$ & $1960 \pm 165$ \\
\hline TR-21 & $0.97 \pm 0.53$ & $10.04 \pm 1.82$ & 1.60 & $2.77 \pm 0.18$ & $5.51 \pm 0.28$ & $1985 \pm 166$ \\
\hline TR-22 & $1.80 \pm 0.54$ & $9.11 \pm 1.84$ & 1.62 & $2.96 \pm 0.20$ & $5.64 \pm 0.20$ & $1907 \pm 146$ \\
\hline TR-23 & $1.50 \pm 0.53$ & $8.82 \pm 1.81$ & 1.45 & $2.69 \pm 0.11$ & $15.79 \pm 1.97$ & $5868 \pm 772$ \\
\hline TR-24 & $2.46 \pm 0.67$ & $7.14 \pm 2.32$ & 1.63 & $2.99 \pm 0.21$ & $6.68 \pm 0.23$ & $2233 \pm 171$ \\
\hline Bharmasar & $1.13 \pm 0.60$ & $8.56 \pm 2.06$ & 1.51 & $2.62 \pm 0.14$ & $29.33 \pm 3.10$ & $11,211 \pm 1332$ \\
\hline TR-25 & & & & & & \\
\hline TR-26 & & & & & & \\
\hline
\end{tabular}

Thirana (TL)

\begin{tabular}{lcccccc}
\hline Sample & $\mathrm{U}(\mathrm{ppm})$ & $\mathrm{Th}(\mathrm{ppm})$ & $\mathrm{K}(\%)$ & $D_{e}(\mathrm{~Gy} / \mathrm{ka})$ & $\begin{array}{c}\text { Dose rate } \\
\text { (Gy/ka) }\end{array}$ & Age $(\mathrm{ka})$ \\
\hline TR-65 & $1.87 \pm 0.91$ & $10.35 \pm 3.14$ & 1.68 & $10.69 \pm 0.83$ & $2.94 \pm 0.34$ & $3.6 \pm 0.5$ \\
\hline TR-66 & $1.91 \pm 0.65$ & $7.68 \pm 2.21$ & 1.59 & $12.04 \pm 1.91$ & $2.67 \pm 0.26$ & $4.5 \pm 0.8$ \\
\hline TR-67 & $2.46 \pm 0.63$ & $5.99 \pm 2.17$ & 1.5 & $12.41 \pm 1.11$ & $2.59 \pm 0.25$ & $4.8 \pm 0.6$ \\
\hline TR-69 & $2.25 \pm 0.70$ & $7.36 \pm 2.38$ & $1.5^{*}$ & $1.26 \pm 1.42$ & $2.64 \pm 0.27$ & $0.5 \pm 0.5$ \\
\hline TR-70 & $2.21 \pm 0.65$ & $7.99 \pm 2.22$ & $1.5^{*}$ & $2.22 \pm 0.86$ & $2.68 \pm 0.26$ & $0.8 \pm 0.3$ \\
\hline TR-72 & $2.58 \pm 0.66$ & $7.31 \pm 2.27$ & $1.5^{*}$ & $20.45 \pm 0.46$ & $2.71 \pm 0.26$ & $7.5 \pm 0.8$ \\
\hline TR-73 & $2.66 \pm 0.75$ & $7.45 \pm 2.55$ & $1.5^{*}$ & $19.68 \pm 1.08$ & $2.74 \pm 0.29$ & $7.1 \pm 0.9$ \\
\hline TR-75 & $2.42 \pm 0.74$ & $7.47 \pm 0.54$ & $1.5^{*}$ & $3.20 \pm 1.97$ & $2.69 \pm 0.29$ & $11.6 \pm 1.4$ \\
\hline TR-76 & $1.95 \pm 0.74$ & $9.22 \pm 2.52$ & $1.5^{*}$ & $26.98 \pm 1.79$ & $2.71 \pm 0.29$ & $10.0 \pm 1.2$ \\
\hline TR-77 & $1.36 \pm 0.71$ & $9.44 \pm 2.45$ & $1.5^{*}$ & $1.29 \pm 0.46$ & $2.59 \pm 0.28$ & $0.5 \pm 0.2$ \\
\hline TR-78 & $2.70 \pm 0.69$ & $6.74 \pm 2.30$ & $1.5^{*}$ & $1.02 \pm 1.72$ & $2.70 \pm 0.27$ & $0.4 \pm 0.6$ \\
\hline TR-79 & $2.31 \pm 0.74$ & $8.54 \pm 2.52$ & $1.5^{*}$ & $14.26 \pm 1.17$ & $2.74 \pm 0.29$ & $5.2 \pm 0.70$ \\
\hline
\end{tabular}

Khudala (GLSL ages)

\begin{tabular}{|c|c|c|c|c|c|c|c|c|}
\hline Litho-Unit & $\begin{array}{l}\text { Sample } \\
\text { Number }\end{array}$ & $\begin{array}{l}\text { Depth } \\
(\mathrm{m})\end{array}$ & $\mathrm{U}(\mathrm{ppm})$ & Th (ppm) & $\mathrm{K}(\%)$ & $D_{e}(\mathrm{~Gy})$ & $\begin{array}{l}\text { Dose rate } \\
\left(\mathrm{Gy} \mathrm{ka}^{-1}\right)\end{array}$ & Age (ka) \\
\hline V & TE-101 & 1.0 & 1.50 & 9.16 & 1.32 & $7.4 \pm 1.9$ & 2.36 & $3.11 \pm 0.8$ \\
\hline $\mathrm{V}$ & TR-102 & 1.6 & 2.03 & 6.42 & 1.20 & $18.2 \pm 6.7$ & 2.23 & $8.1 \pm 3.1$ \\
\hline $\mathrm{V}$ & TR-106 & 6.0 & 1.58 & 6.57 & 1.30 & $23.7 \pm 8.5$ & 2.25 & $10.5 \pm 3.9$ \\
\hline IV & TR-108 & 7.4 & 1.04 & 8.15 & 1.50 & $21.5 \pm 8.8$ & 2.42 & $9.5 \pm 4.0$ \\
\hline IV & TR-110 & 9.0 & 2.47 & 1.94 & 1.83 & $22.9 \pm 2.4$ & 2.56 & $9.5 \pm 1.1$ \\
\hline IV & TR-12 & 10.0 & 0.35 & 6.15 & 1.73 & $25.3 \pm 8.4$ & 2.28 & $11.7 \pm 4.0$ \\
\hline IV & TR-115 & 12.5 & 1.87 & 9.53 & 1.42 & $62 \pm 13$ & 2.4 & $25.8 \pm 5.5$ \\
\hline III & TR-116 & 12.5 & 1.28 & 12.1 & 1.85 & $150 \pm 62$ & 2.85 & $52.4 \pm 21.8$ \\
\hline III & TR-117 & 14.5 & 2.2 & 6.7 & 1.8 & $227 \pm 75$ & 2.63 & $86.3 \pm 28.5$ \\
\hline
\end{tabular}


Shergarh trijunction (GLSL ages)

\begin{tabular}{lccccc}
\hline \multicolumn{1}{c}{$\begin{array}{c}\text { Alpha Count } \\
\text { Sample }\end{array}$} & \multicolumn{3}{c}{ Dose rate $^{a}$} & & \\
$\left(\mathrm{c} / \mathrm{ksec} / \mathrm{cm}^{2}\right)$ & $\mathrm{K} \%$ & $(\mathrm{~Gy} / \mathrm{ka})$ & $D_{e}(\mathrm{~Gy})$ & Age $(\mathrm{ka})$ \\
\hline ARD 1 (aeolian V) & 0.58 & 1.56 & $3.65 \pm 0.21$ & $29 \pm 2$ & $9 \pm 1$ \\
\hline ARD 2 (aeolian V) & 0.58 & 1.49 & $4.09 \pm 0.32$ & $38 \pm 3$ & $9 \pm 2$ \\
\hline ARD 3 (aeolian IV) & 0.46 & 1.79 & $3.08 \pm 0.22$ & $133 \pm 13$ & $43 \pm 5$ \\
\hline ARD 4 (aeolian III) & 0.49 & 1.35 & $2.73 \pm 0.18$ & $150 \pm 14$ & $55 \pm 6$ \\
\hline ARD 5 (aeolian II) & 0.48 & 1.28 & $2.63 \pm 0.18$ & $168 \pm 11$ & $64 \pm 6$ \\
\hline ARD 6 (aeolian I) & 0.55 & 1.98 & $3.50 \pm 0.25$ & $211 \pm 33$ & $60 \pm 10$ \\
\hline
\end{tabular}

${ }^{a}$ This assumes average water content of $5 \%$ by weight and a cosmic ray dose of $150 \mu \mathrm{Gy} / \mathrm{yr}, \mathrm{ED}$, equivalent dose.

\section{References}

Allchin B, Goudie A and Hegde K T M 1978 The Prehistory and Palaeogeography of the Great Indian Desert. (London Academic Press) 370 p.

Andrews J E, Singhvi A K, Kailath A J, Kuhn R, Dennis P F, Tandon S K and Dhir R P 1998 Do stable isotope data from calcrete record Late Pleistocene monsoonal climate variation in the Thar desert of India?; Quat. Res. $50240-251$

Bajpai V N, Saha Roy T K and Tandon S K 2000 Subsurface sediment accumulation patterns and their relationship with tectonic lineaments in semi-arid Luni river basin, Rajasthan, western India; J. Arid Env. 48603 621

Bakliwal P C and Wadhawan S K 2003 Geological Evolution of Thar Desert in India _ Issues and Prospects; Proc. Indian Natn. Sci. Acad. 69A 151-166

Bateman M D, Thomas D S G and Singhvi A K 2003 Extending the aridity record of the southwest Kalahari: current problems and future perspectives; Quaternary International $11137-49$

Bryson R A 1989 Modelling the NW India monsoon for the last 40000 years; Climate Dynamics 3 169-177

Chawla S, Dhir R P and Singhvi A K 1992 Thermoluminescence chronology of sand profiles in the Thar desert and their implications; Quat. Sci. Rev. 11 2532

Chougaonkar M P, Raghav K S, Rajaguru S N, Kar A, Singhvi A K and Nambi K S V 1999 Luminescence dating results of dune profiles from the margins of the Thar desert and their implications. Man and Environment, 24(1) 21-26

Cooke R U, Warren A and Goudie A 1993 Desert Geomorphology. (London: UCL Press) $526 \mathrm{p}$.

Deotare B C, Kajale M D, Kshirsagar A A and Rajaguru S N 1998 Geoarchaeological and palaeoenvironmental studies around Bap-Malar playa, district Jodhpur, Rajasthan; Current Science $\mathbf{7 5}$ 316-320

Dhir R P 1995 The genesis and distribution of arid zone calcretes; Memoirs Geological Society of India 32 191209

Dhir R P, Rajaguru S N and Singhvi A K 1994 Desert Quaternary formations and their morphostratigraphy: Implications for the evolutionary history of the Thar; J. Geol. Soc. India 43 435-447

Glennie K W and Singhvi A K 2002 Event stratigraphy, paleoenvironment and chronology of SE Arabian deserts; Quat. Sci. Revs. 21 853-869
Goudie A S and Sperling C H B 1977 Long distance transport of foraminiferal tests by winds in the Thar Desert, NW India; J. Sed. Petrol. 47 630-633

Goudie A S, Allchin B and Hegde K T M 1973 The former extensions of the Great Indian Sand Desert; The Geographical Journal $139243-257$

Jain M, Tandon S K, Bhatt S C, Singhvi A K and Mishra S 1999 Alluvial and aeolian sequences along the River Luni, Barmer district: Physical stratigraphy and feasibility of luminescence chronology methods; Memoir Geological Society of India 42 273-295

Juyal N, Kar A, Rajaguru S N and Singhvi A K 2003 Luminescence chronology of aeolian deposition during the late Quaternary on the southern margin of Thar Desert, India; Quat. International, 104 87-98

Kailath A J, Rao T K G, Dhir R P, Nambi K S V, Gogte V D and Singhvi A K 2000 Electron Spin Resonance characterization of calcretes from Thar desert for dating applications, Rad. Meas. 32 371-383

Kajale M D and Deotare B C 1997 Late Quaternary environmental studies on salt lakes in western Rajasthan, India: A summarised view, J. Quat. Sci. 12 405-412

Kameshwara Rao K, Wasson R J and Krishnan K 1989 Foraminifera from late Quaternary dune sands of Thar Desert; Palaios 4 168-180

Kar A 1987 Origin and transformation of longitudinal sand dunes in the Indian desert; Zeitschrift fur Geomorphologie 31 311-337

Kar A 1990a The megabarchanoids of the Thar: Their environment, morphology and relationship with longitudinal dunes; The Geographical Journal 156 51-61

Kar A 1990b A stream trap hypothesis for the evolution of some saline lakes in the Indian desert; Zeitschrift fur Geomorphologie 34(1) 37-47

Kar A 1993a Aeolian processes and bedforms in the Thar desert; J. Arid Environments 25 83-96

Kar A 1993b Present day geomorphic processes as key to the reconstruction of Quaternary landform history in the Thar Desert; J. Geol. Soc. India 41(6) 513517

Kar A 1994 Sand dunes and their mobility in Jaisalmer district. In: India: Geomorphological Diversity K R Dikshit, V S Kale, and M N Kaul (eds.), (Jaipur: Rawat Publications) pp. $395-418$

Kar A 1996 Morphology and evolution of sand dunes in the Thar desert as key to sand control measures; Indian Journal of Geomorphology 1(2) 177-206

Kar A 1997 Comments on paper "Regional stratigraphy of Quaternary deposits in parts of Thar desert, Rajasthan" 
by R M Sundaram and others; J. Geol. Soc. India 49 $607-610$

Kar A 1998 Present-day mobile crescentic dunes in the Thar desert, India. In: Quaternary Deserts and Climatic Change A.S.Alsharhan, K.W.Glennie, G.L.Whittle and C.G.St.C. Kendall (eds.), A.A. Balkema, Rotterdam (Netherlands) and Brookfield (USA); pp. 155-164

Kar A 1999 Quaternary period in Rajasthan: Geomorphic process response to forcing and implications for terrain evolution. In: Geology of Rajasthan: Status and Perspective P. Kataria (ed.), M.L. Sukhadia University, Udaipur; pp. $175-212$

Kar A 2002 Granulometry of aeolian bedforms in the extremely arid Jaisalmer region of Thar Desert. In: Recent Advances in Geomorphology, Quaternary Geology and Environmental Geosciences: Indian Case Studies. S.K. Tandon and B. Thakur (eds), (New Delhi: Manisha Publications) pp. 261-286

Kar A, Felix C, Rajaguru S N and Singhvi A K 1998a Late Holocene growth and mobility of a transverse dune in the Thar desert; Journal of Arid Environments 38(2) 175185

Kar A, Rajaguru S N, Singhvi A K, Juyal N, Thomas J V, Kailath A and Chougaonkar M 1998b Aeolian processes and sand accretion in the Thar desert during the late Quaternary period. Abstracts, IGCP (349/413) Workshop on Palaeoclimatic Records on Arid and Semi-arid Regions During the Late Quaternary Deccan College, Pune, p. 15

Kar A, Tsunekawa A and Miyazaki T 1998c Potentiality of global positioning system in sand dune measurement: A case study from the Thar desert, India. In: Quaternary Deserts and Climatic Change A.S. Alsharhan, K.W. Glennie, G.L. Whittle and C.G.St.C. Kendall (eds.), A.A. Balkema, Rotterdam (Netherlands) and Brookfield (USA); pp. 433-438

Kar A, Singhvi A K, Rajaguru S N, Juyal N, Thomas J V, Banerjee D and Dhir R P 2001 Reconstruction of late Quaternary environment of the lower Luni plains, Thar desert, India; Journal of Quaternary Science 16 6168

Kocurek G 1988 First-order and super bounding surfaces in eolian sequences - Bounding surfaces revisited; Sedimentary Geology 56 193-206

Kocurek G 1991 Interpretation of ancient eolian sand dunes; Annual Review of Earth and Planetary Sciences 19 43-75

Lancaster N 1995 Geomorphology of Desert Dunes (London: Routledge)

Lancaster Nicholas, Kocurek Gary, Singhvi Ashok, Pandey V, Deynoux Max, Ghienne J-F and Lo Khalidou 2002 Late Pleistocene and Holocence dune activity and wind regimes in the western Sahara Desert of Mauritania; Geology 30 991-994

Mishra V N and Rajaguru S N 1994 Environnemet et culture de L'Homme prehistorique dans le Desert du Thar, Rajasthan; Inde. L'Anthropologie 90 407-437

Mishra S, Jain M, Tandon S K, Singhvi A K, Joglekar P P, Bhatt S C, Kshirsagar A, Naik S Mukherjee A D 1999 Prehistoric cultures and late quaternary environments in the Luni basin around Balotara; Man and Environment $2438-49$

Naruse T 1985 Aeolian geomorphology of the Punjab plains and the north Indian desert; Annals of Arid Zone $24267-$ 280

Overpeck J, Anderson D, Trumbore S and Prell W 1996 The southwest Indian monsoon over the last 18000 years; Climate Dynamics 12 213-225

Pandey S, Singh S and Ghose B 1964 Orientation, distribution and origin of sand dunes in the central Luni basin; Proceedings, Symposium on Problems of Indian Arid Zone CAZRI, Jodhpur, pp. 84-91

Pye K and Tsoar H 1990 Aeolian Sand and Sand Dunes (London: Unwin and Hyman) 396 p.

Raghavan H, Rajaguru S N and Misra V N 1989 Radiometric dating of a Quaternary dune section, Didwana, Rajasthan; Man \& Environment 13 19-22

Schulz H, von Rad U and Erlenkeuser H 1998 Correlation between Arabian Sea and Greenland climate oscillations of the past 110,000 years; Nature 393 54-57

Singh G, Joshi R D, Chopra S K and Singh A B 1974 Late Quaternary history of vegetation and climate of the Rajasthan desert, India; Philosophical Transaction of the Royal Society, London, B267 467-501

Singh G, Wasson R J and Agrawal D P 1990 Vegetational and seasonal climatic changes since the last full glacial in the Thar desert, northwestern India; Review of Palaeobotany and Palynology 64 351-358

Singh S 1982 Types and formation of sand dunes in Rajasthan desert. In: Perspectives in Geomorphology. Concept, H.S. Sharma (ed.), New Delhi, pp. 165-183

Singhvi A K and Kar A (eds.) 1992 Thar Desert in Rajasthan (Bangalore: Geological Society of India), 191 p.

Singhvi A K and Krbetschek M R 1996 Luminescence dating: A review and a perspective for arid zone sediments; Annals of Arid Zone 35 249-279

Singhvi A K, Sharma Y P and Agrawal D P 1982 Thermoluminescence dating of sand dunes in Rajasthan, India; Nature 295 313-315

Singhvi A K, Banerjee D, Rajaguru S N and Kishan Kumar V S 1994 Luminescence chronology of a fossil dune at Budha Pushkar, Thar desert: Palaeoenvironmental and archaeological implications; Current Science $\mathbf{6 6}$ 770-773

Sinha Roy S, Malhotra G and Mohanty M 1998 Geology of Rajasthan. (Bangalore: Geological Society of India.)

Sirocko F 1994 Abrupt change in monsoonal climate: evidence from the geochemical composition of Arabian Sea sediments. Ph. D. thesis, MathematischNaturwissenschaftliche Fakultat der Christian-AlbrechtsUniversitat zu Kiel, 161 p.

Sirocko F 1996 The evolution of the monsoon climate over the Arabian Sea during the last 24,000 years; Palaeoecology of Africa and the Surrounding Islands 2453 69

Sundaram R M, Rakshit P and Pareek S 1996 Regional stratigraphy of Quaternary deposits in parts of Thar desert, Rajasthan; J. Geol. Soc. India 48 203-210

Tandon S K, Jain M and Singhvi A K 1999 Comparative development of mid- to late Quaternary fluvial and fluvioaeolian stratigraphy in the Luni, Sabarmati and Mahi river basins of western India; Gondwana Geology Magazine, Special vol. 4, pp. 1-16

Tandon S K, Sareen B K, Someshwara Rao M and Singhvi A K 1996 Aggradation history and luminescence chronology of late Quaternary semi-arid sequences of the Sabarmati basin, Gujarat; Palaeogeography, Palaeoclimatology, Palaeoecology, 128 339-357

Tchakerian V P 1994 Palaeoclimatic interpretations from desert dunes and sediments. In: Geomorphology of Desert Environments A D Abrahams and A J Parsons (eds.), (London: Chapman \& Hall) pp. 631-643

Thomas J V, Kar A, Kailath A J, Juyal N, Rajaguru S N and Singhvi A K 1999 Late Pleistocene - Holocene history of aeolian accumulation in the Thar desert, India; Zeitschrift fur Geomorphologie Supplement Band 116 181194

Verstappen H Th 1968 On the origins of longitudinal (seif) dunes; Zeitschrift fur Geomorphologie 12 200-220 
von Rad U, Schaaf M, Michels K H, Schulz H, Berger W and Sirocko F 1999 A 5000-yr record of climate change in varved sediments from the Oxygen Minimum Zone off Pakistan, northeastern Arabian Sea; Quaternary Research 51 39-53

Wadhawan S K 1988 Evolution of Quaternary aeolian deposits of Jodhpur and Barmer districts, Rajasthan, India. In: Proceedings, National Seminar on Recent Quaternary Studies in India. M.P. Patel and N. Desai (eds.), M.S. University, Baroda, pp. 64-78

Wadhawan S K 1996 Textural attribute of recent aeolian stratigraphy in the Ghaggar basin of Thar desert, India; Journal of Arid Environments 32 59-74
Wasson R J, Rajaguru S N, Misra V N, Agrawal D P, Dhir R P, Singhvi A K and Rao K K 1983 Geomorphology, late Quaternary stratigraphy and palaeoclimatology of the Thar dunefield; Zeitschrift fur Geomorphologie, Supplememt band 45 117-151

Yan Z W and Petit-Maire N 1994 The last 140 ka in the Afrao-Asian climatic transition zone; Palaeogeog. Palaeoclim. Palaeoecol. 110 217-233

Zonneveld K A F, Ganssen G, Troelstra S, Versteegh G J M and Visscher H 1997 Mechanisms forcing abrupt fluctions of the Indian Ocean summer monsoon during the last deglaciation; Quaternary Science Reviews 16 187201 